\title{
Innovative mining machinery solutions developed at Department of Mining, Dressing, and Transport Machines, AGH University of Science and Technology
}

\begin{abstract}
The exploitation of mineral resources with underground mining methods is becoming more and more difficult due to the mining and geological conditions in which these resources are present. This is related to the depth of retention and thickness of the exploited deposits (seams), more cohesive and durable rocks, and climatic conditions. The excavation of access and preparatory roadways as well as exploitation under such conditions require specially designed and manufactured machines. In recent years in the Department of Mining, Dressing, and Transport Machine at AGH University of Science and Technology in Krakow, a number of innovative solutions of machines and devices have been developed that can be used to work under difficult mining and geological conditions. This article presents selected solutions of these machines and devices - a mining head for a roadheader with asymmetrical disc tools with a complex motion trajectory, a temporary, mechanized, and walking roadway support, a unique longwall complex with a single-cutting head shearer used for thin coal seam exploitation, and an innovative mining and hauling system for mechanical shaft drilling using a shaft shearer.
\end{abstract}

Key words: innovative solutions, mining machines, hard rock mining, performance, safety

\section{INTRODUCTION}

The mining and geological conditions under which the mineral raw materials exploited by underground methods are covered are becoming more and more difficult in Poland. This is related to the greater depths of their retention, climatic conditions, and harder and harder rocks. This means that the currently used technologies of opening-out and excavating minerals are increasingly unreliable or do not allow us to achieve satisfactory performance. In order to meet this problem, the Department of Mining, Dressing, and Transport Machines has been working for many years on developing machines and devices that will be able to work efficiently under difficult mining conditions.

First, a number of unique research stands have been developed and completed, on which research on the use of new mining tools and techniques for the mining of compact rocks have been conducted. These are, among others, a laboratory standstands for rock mining using single tools (Fig. 1a), rock mining using disc tools (Fig. 1b), and rock mining with milling screw heads (Fig. 1c).

The results of the tests carried out on these stands (shown in Figure 2) have allowed for the development of new tools and cutting heads that can be used while mining hard and very compact rocks. The most promising direction is the use of mini symmetrical and asymmetrical disk tools in the rock mining process and the so-called undercutting technique. This technique allows us to reduce the energy consumption of the mining process and increase the granulation of the output as compared to the technique of milling or static crushing. 
a)

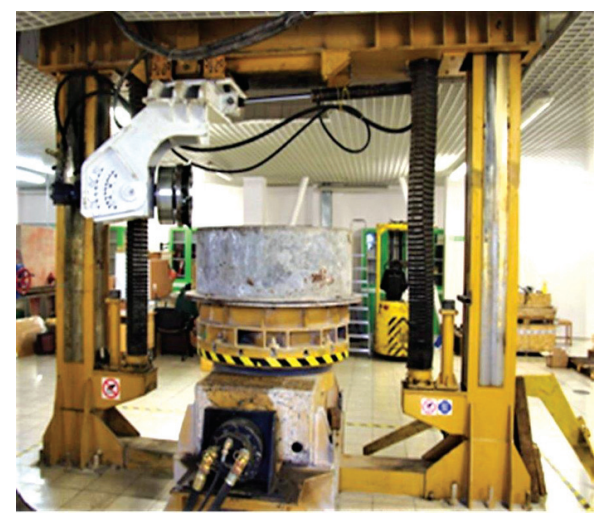

b)

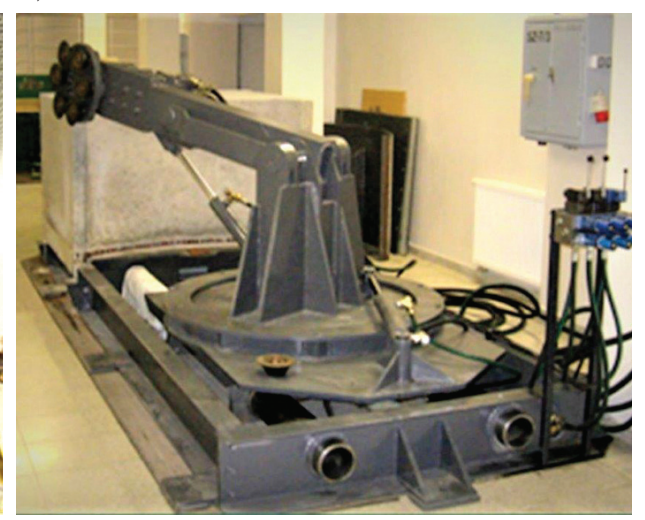

c)

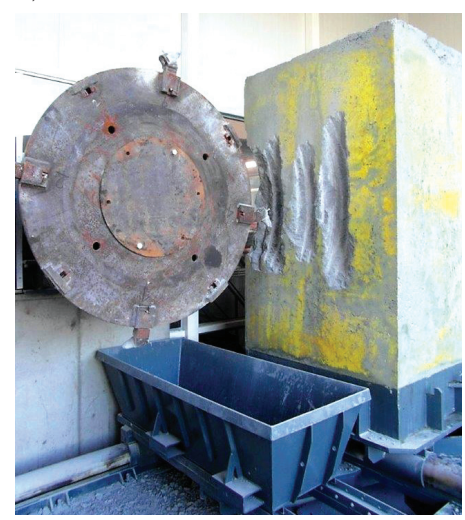

Fig. 1. Laboratory stands for testing rock mining: a) with single tools; b) with disk tools;

c) with screw milling heads

a)

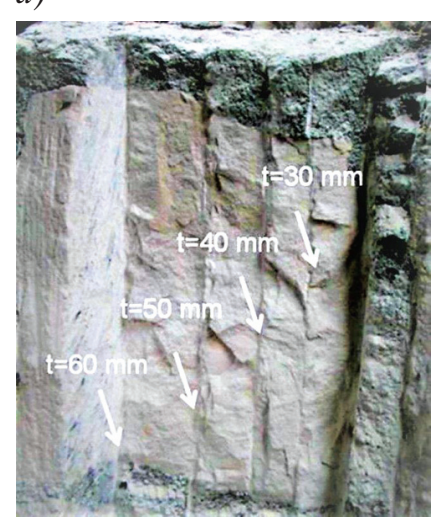

b)

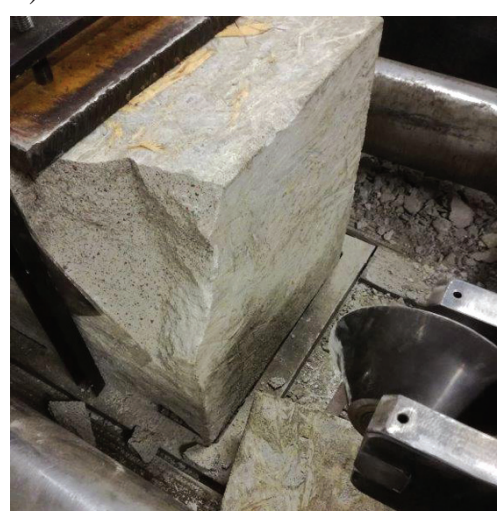

c)

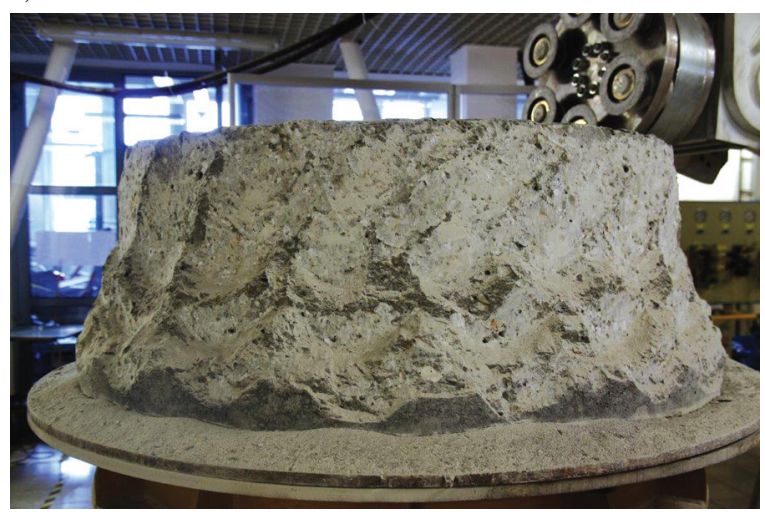

Fig. 2. Results of tests of rock mining using: a) single plate with disk tools with simple trajectory; b) single disk tool; c) single plate with disk tools with complex trajectory

However, using the experience gained during the implementation of the research work in the mining industry, it was also proposed to develop atypical and innovative machine solutions that can be used in the exploitation of low coal seams, opening-out heading and tunnel drilling, and shaft drilling. The results of this work conducted at the Department of Mining, Dressing, and Transport Machines are presented in this article.

\section{INNOVATIVE SOLUTION OF MINING HEAD FOR ROADHEADERS}

In Polish underground mining, plenty of dog headings are drilled with mechanical methods using arm roadheaders equipped with milling units. The cutting tools applied on the units (rotary tangent bits) are under unfavorable mining and geological conditions or improper work conditions and are, thus, affected by an accelerated wear process. This influences the speed and cost of drilling such excavations. In the Department of Mining, Dressing, and Transport Machines at AGH University of Science and Technology in Krakow, asymmetrical mini disc tools for use on the mining heads of roadheaders have been proposed. Asymmetrical disc tools are applied in the technique of mechanical mining not only as crushing devices but also as chipping ones. The principle of the incision technique is the mining of a rock by cutting it off towards a free space.

A disc tool affects the rock tangentially to the surface of the mined body (similarly to a cutting tool); however, the difference is that it uses a disc rolling movement, which efficiently eliminates sliding friction in favor of rolling friction. Application of disc tools in this way lowers energy consumption and pressure force, which allows for constructing a mining machine with respectively lower energy parameters and lower requirement concerning stability as compared to classical crushing discs operating perpendicularly towards the surface of the mined body [1-3]. 
On the basis of an analysis of the world technique condition and results of our own tests of rock mining with asymmetrical disk tools, a new conception was elaborated featuring a unit in which the motion of the tools will be forced, causing the mining of a rock body with tools along a complex trajectory. This allows for the crossing of mining lines of individual disc tools and facilitates the mining of compact rocks through breaking off rock furrows. It decreases the energy consumption of the process. In this case, disc tools were mounted on separate plates that are able to rotate on the mining unit casing and are propelled independently from it.

The project and model of the new solution of a mining head with disc tools of a complex trajectory were performed in cooperation with the REMAG company (currently FAMUR Ltd.) - the leading Polish producer of roadheaders. It was planned to work out and adapt the new head solution for the KR 150 medium roadheader manufactured by REMAG. On the basis of an analysis of the milling heads used on the miner, it was assumed that the length of the new solution should not exceed $1750 \mathrm{~mm}$, with a diameter of less than $859 \mathrm{~mm}$ and weighing less than 5 tons. The elaborated initial model of the head was comprised of mounting three plates with disc tools on its body. The casing body will have the ability of independent rotation as related to plates with disc tools. The kinematic capabilities of the new head solution are presented in Figure 4 [1, 3].

On the basis of the elaborated model, a technical design and prototype of the head were developed for mounting on the KR 150 miner and the initial field tests in REMAG Ltd. These tests were carried out on a large-size concrete block of a uniaxial compressive strength of about $80 \mathrm{MPa}$.
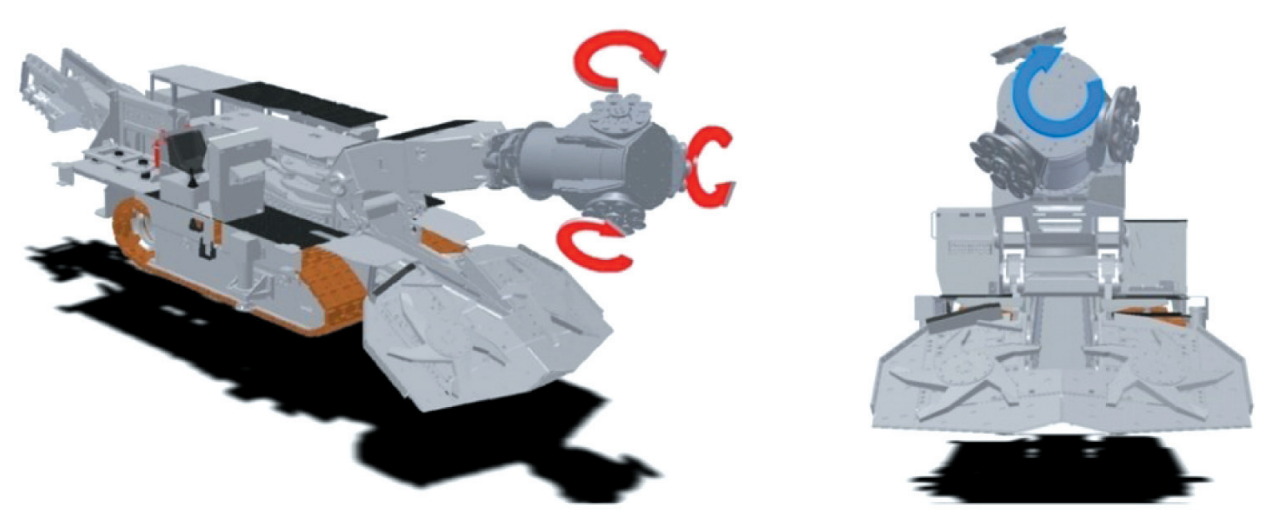

Fig. 3. Kinematic capabilities of new head solution mounted on roadheader KR 150 [3]

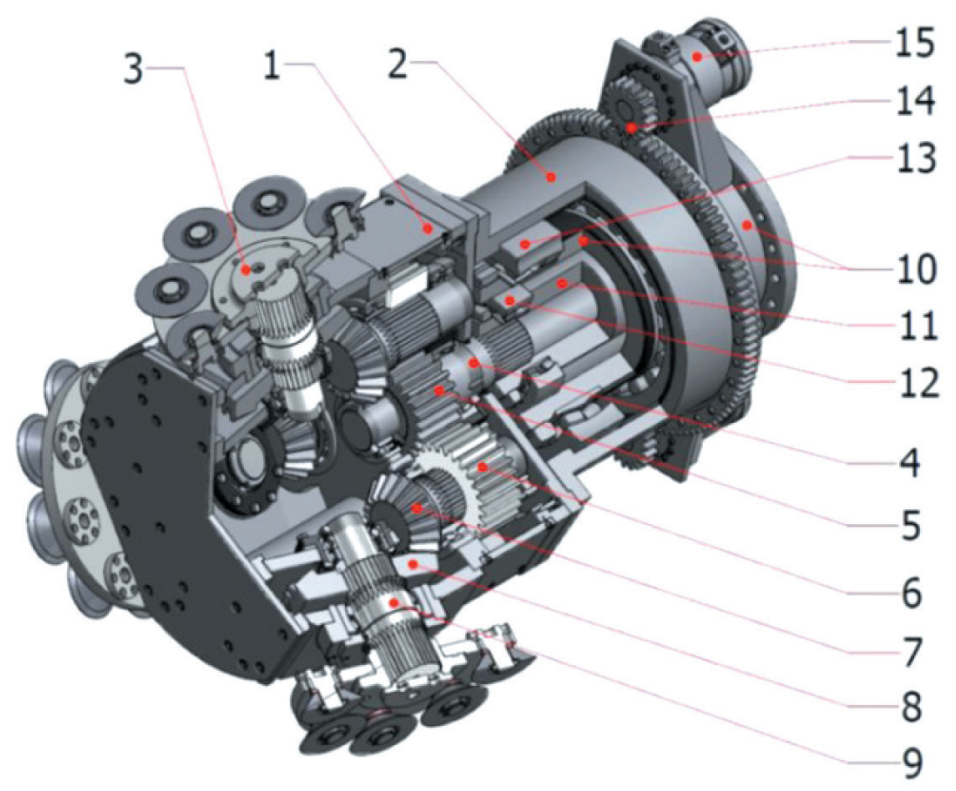

Fig. 4. Model of new head solution with disc tool of complex trajectory [3]: 1 - main gear, 2 - auxiliary gear, 3 - disc plate, 4 - input shaft, 5 - central gear wheel, 6 - orbital gear wheel, 7 - pinion, 8 - face gear, 9 - output shaft, 10 - support, 11 - connector, 12 and 13 - bearings, 14 - body gear, 15 - hydraulic engine 
The best effects of the work - the large graining of the winning, low engine load, and limited vibrations - were obtained for the head body rotations of ca $20 \mathrm{rpm}$ at a plates rotation value of ca $60 \mathrm{rpm}$, with the head body rotating in a counter-clockwise direction and the plates with the disc tools rotating in a clockwise direction.

No considerable symptoms of disc tool wear were noticed for these working parameters. A view of the obtained winning and a typical surface of the mined block (intersection of the cutting lines) is shown in Figure 5.

An increase in the rotations of the plates with disc tools increased the dustiness, and at maximal rotation, sparking even occurred at the contact of the tools with the rock. Whereas, a change of the direction of the head body or the plates with disc tools rotating in the opposite direction had a highly negative influence on the engine load as well as excess wear on the disc tools and plates themselves.

The wear of the plates with disk tools is eliminated by modifying the design of these plates. Instead of flat and round plates, plates in the shape of flowers were built, with external elements tilted at an angle of about $-15^{\circ}$. A view of such a modified plate is shown in Figure 6a. In subsequent tests, no wear was found in the plates. For the next tests, another plate and a universal disc tool holder were designed to allow the disc tool to be mounted in at least three positions by twisting it on a plane passing through the plate's axis. The version with an interchangeable monoblock for three disk tool settings in relation to the disk (at $-5^{\circ}, 45^{\circ}$, and $90^{\circ}$ angles in relation to the plate axis) was adopted as the most advantageous. Figure $6 \mathrm{~b}$ shows a plate view with monoblocks in a version that allows for mounting disk tools perpendicular to the axis of the disk; i.e., at an angle of $90^{\circ}$.

The tests performed for the disk tools mounted at angles of $-5^{\circ}, 45^{\circ}$, and $90^{\circ}$ with respect to the plate axis have shown that setting the tools at an angle other than $-5^{\circ}$ to $-15^{\circ}$ results in serious damage in a very short time in the form of chipping and breaking the edges of the tools. Therefore, in the next tests,

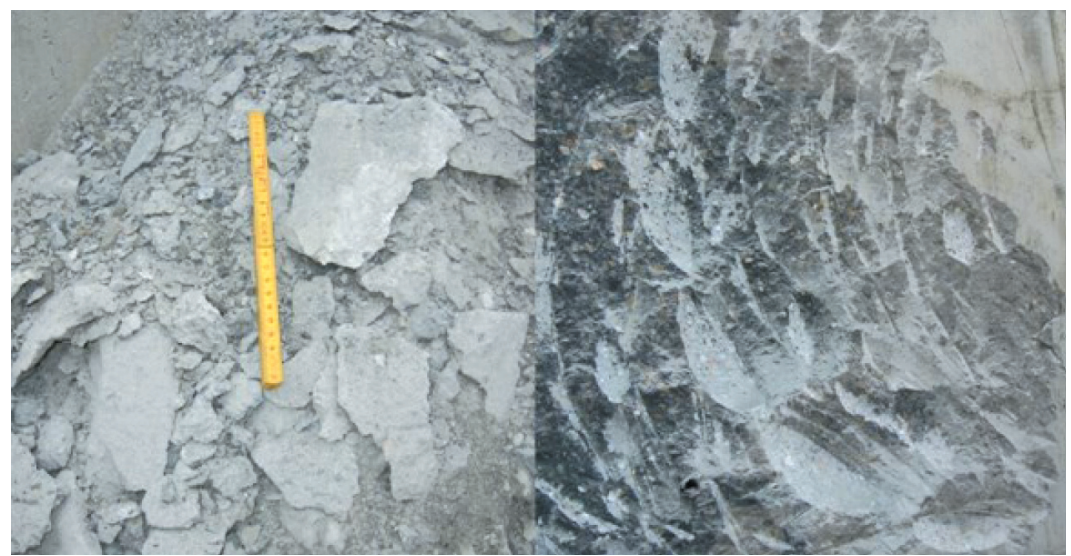

Fig. 5. View of winning and surface of mined rock block obtained for most favorable set of direction and revolution number of head body and plates with tools [2]

a)

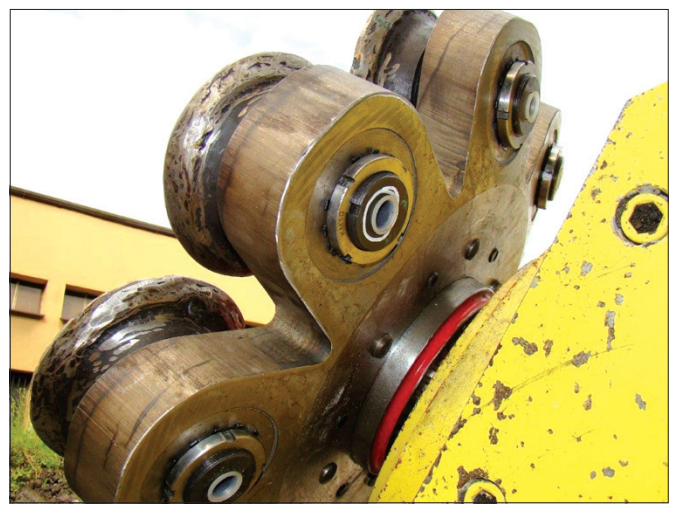

b)

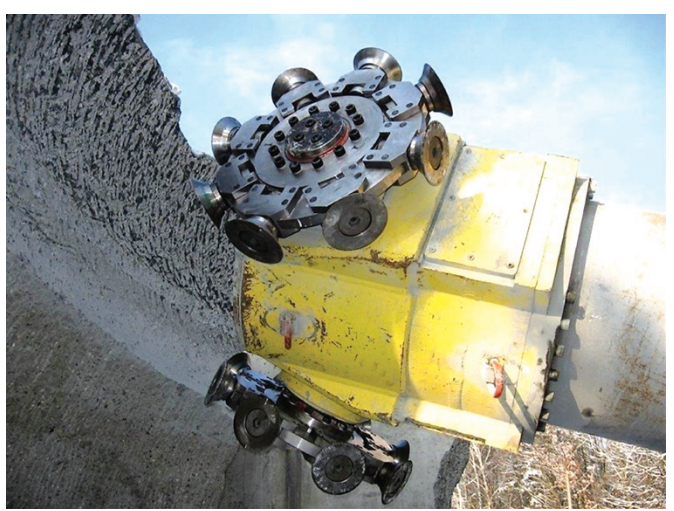

Fig. 6. View of: a) modified solution of plate with disk tools mounted at $-5^{\circ}$ angle; b) new universal solution of plate with disk tools mounted in interchangeable holders at $90^{\circ}$ angle [2] 
the disc tools were mounted only in the holders at an angle of $-5^{\circ}$. Attempts to install tools armed on the perimeter with sintered carbide insertsinstead of smooth disk tools was also unsuccessful. In addition, after a very short period of operation, these tools were seriously damaged - a large number of carbide inserts were broken off. The views after the attempts of the disk tools mounted at an angle of $90^{\circ}$ and the disk tools armed with sintered carbide inserts are shown in Figure 7 (and are compared to smooth discs mounted at an angle of $-5^{\circ}$ ).

The new mining head solution has been adapted for mounting on the produced by FAMUR S.A. FR 250 roadheader arm (Fig. 8), which has greater power and is heavier. The conducted concrete block mining tests showed that this roadheader is more suitable for using the disc mining head than the KR 150 roadheader. The mining head worked in a much more stable fashion.

a)

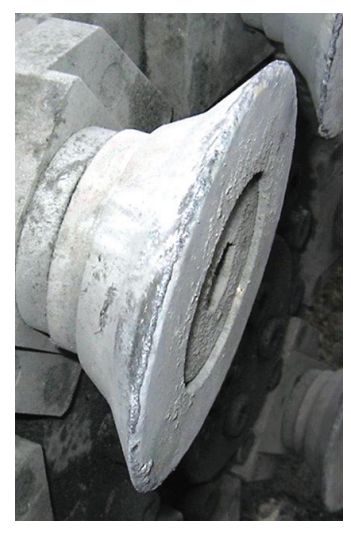

b)

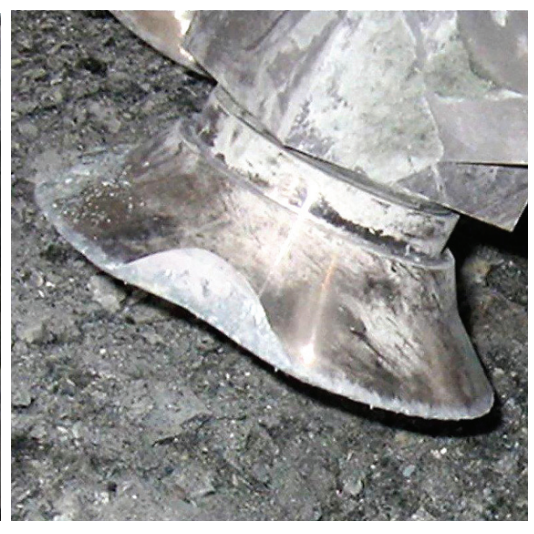

The proposed solution of the mining head with asymmetrical disk tools with the complex trajectory of motion showed its usefulness during the mining of hard rocks; it can be used as an alternative to the milling heads of the roadheaders. In order to obtain the best working parameters of the mining head (large grain size of the output, low load of the drive motors, and limited vibrations), it is also necessary to choose the right direction and rotary speed value of the mining head body and plates with the disk tools. However, it is purposeful to carry out further tests to develop the technology of its operation during the excavation of galleries and tunnels.

On the basis of the results of the conducted field tests, it was also found that the method of their setting in relation to the discs axis and the material from which they were made are very important for the efficiency of the mining and durability of the disc tools. c)

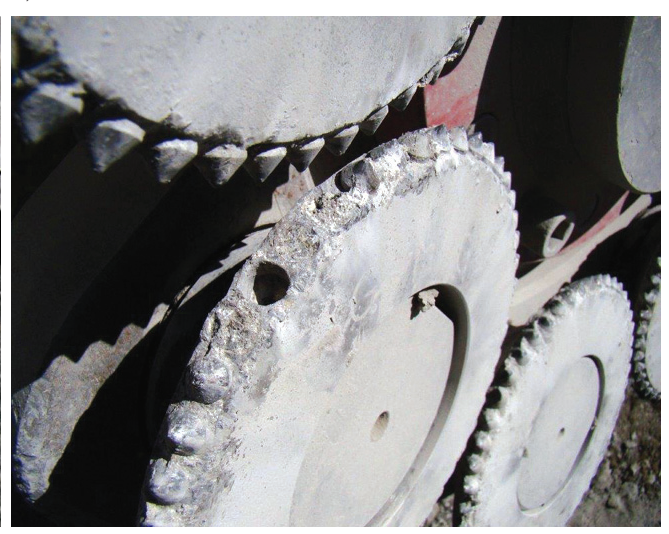

Fig. 7. View of wear of disk tools after mining tests: a) mounted under $-5^{\circ}$ angle; b) mounted under $90^{\circ}$ angle; c) armored with carbide inserts [2]

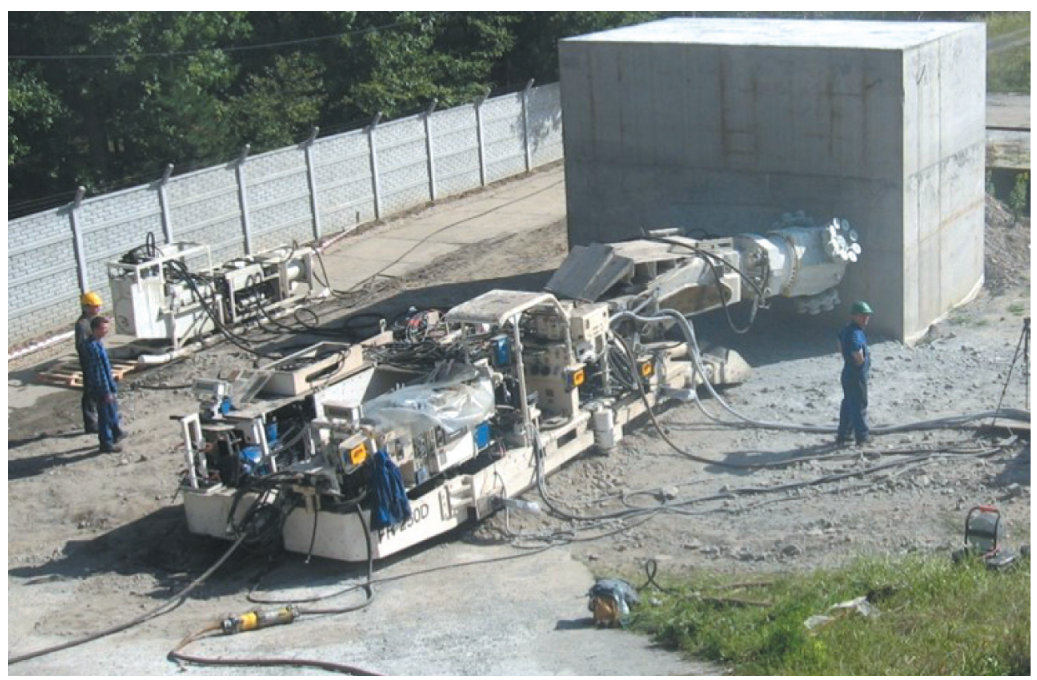

Fig. 8. View of mining head with disc tools mounted on type FR 250 roadheader during field tests 
The most favorable is to set them so that the axis of rotation of these tools is inclined at an angle within a range of $-5^{\circ}$ to $-15^{\circ}$ relative to the axis of plate rotation. It is also suggested to include an automatic arm control system to ensure smooth movement of the mining head in a future solution.

\section{TEMPORARY, WALKING, MECHANIZED MINE ROADWAY SUPPORT}

In the process of gallery drilling, regardless of the drill method used (drilling and blasting material firing or mechanical mining), one of the longer-lasting operations is the assembly of a gallery lining. It often absorbs up to $40 \%$ of the total time spent for gallery drilling. Reducing the time of this operation is possible, for example, by using mechanized work platforms, allowing for the assembly of large lining elements outside the gallery face and transporting them to the face after finishing the mining process. In the Department of Mining, Dressing, and Transport Machines, it was decided to return to the ideas implemented in the 1980s; i.e., a mechanized temporary roadway support. This allows the machines to work under a roof secured by such a support; in parallel, behind this support the process of assembly the final lining is carried out. The temporary linings used at that time did not have great possibilities to adapt to the variable geometric parameters of the gallery; also, their cyclical extending and sliding negatively influenced the condition of the gallery roof [4].
In the Department of Mining, Dressing, and Transport Machines, it was assumed that the support would be adapted for cooperation with both drilling machines - the roadheader and the machines used in the traditional explosive method. In addition, it will be able to increase its length by adding modular segments up to $16 \mathrm{~m}$, and an LP-type arc steel lining will be mounted behind it. Another difference will be the offloading of the floor elements of the support during the movement as well as moving the support in contact with the roof. Based on the above assumptions, a preliminary concept of a temporary mechanized walking support has been developed. It was designed as a modular construction with the possibility of adding or subtracting individual segments $[4,5]$. A view of a support set consisting of six segments is shown in Figure 9.

The support consists of two marginal sets (1) and four identical inside sets (2). In the lower straightlined segment, the arcs are equipped with shift cylinders having a stroke of $300 \mathrm{~mm}^{3}$, whereas the nominal support dimension is obtained for a shift cylinder advance of $150 \mathrm{~mm}$ (the remaining $150 \mathrm{~mm}$ is considered to be a reserve). The individual segments are joined together via four feed cylinders (4). Because of the operational mode, the marginal shift cylinders are two-side acting, and the others are one-side acting. In addition, the arcs are joined together with pipe-type guides (5) assuring their stability during the drawing-off phase. Moreover, a considerable part of the support set is covered with a special shield, which is designed in such a manner that it protects the heading against rock waste, plays the role of

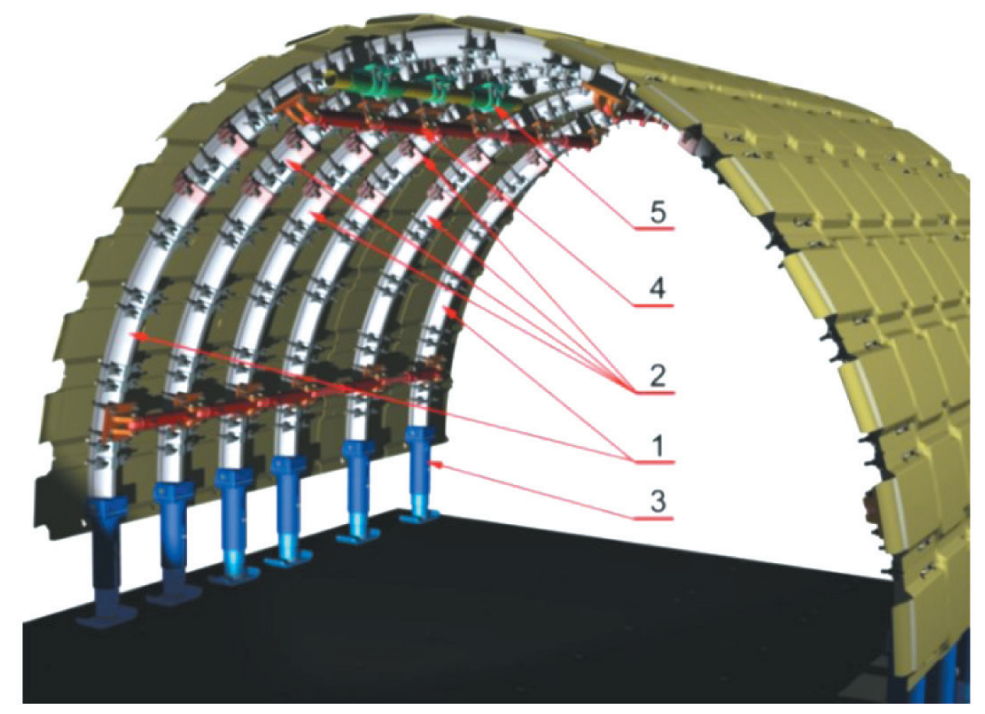

Fig. 9. Model of mechanized temporary roadway support [9]: 1 - marginal sets, 2 - inside sets, 3 - shift cylinders, 4 -feed cylinders, 5 - pipe-type guides 
a guiding element, and allows for sheet metal plates and other equipment to be mounted on the arcs. In the case of the presented solution, the mechanized temporary support is adapted for driving the roadways of cross-sections tailored to the support of LP 9 and LP 10 (depending on the type of applied arcs). Just one set relative advance of the other amounts to $280 \mathrm{~mm}$; this results from the assumed feed cylinder strokes. The scale (i.e., the distance between the individual segments during machine operation with an advanced shift cylinder) amounts to $900 \mathrm{~mm}$ [5].

After installing the support set to the length determined by the type of roadheader or mining and loading machine, it is possible to start the work cycle. As the face of the gallery advances, individual segments of the support are robbed (offloaded) by sliding the hydraulic actuators placed in the support feet (starting from the gallery face and moved forward by means of actuators). After moving the individual segment, it is spread again; then, the sequential moving of the remaining support segments to the last one is carried out. Due to the ratio of the mining web to the stroke of the feed hydraulic actuator, it is assumed to control two or three arc sets in one cycle. For the proper implementation of this operation, it was necessary to develop and execute a control system for individual segments of support.

On the basis of the developed project at the Hydromel Factory, a prototype of a six-element temporary mechanized roadway support with a power supply and control system was made (Fig. 10). During the workplace tests, the support correctly performed all of the assumed activities. The further part of the trials was carried out in the Janina Coal Mine in Libiąż, Poland underground conditions. These tests also showed no major problems during the operation of the new temporary support. Only the hydraulic power and control system should be modified in terms of its automation; currently, the control is carried out manually.

As mentioned above, the temporary support is adapted for cooperation with the roadheaders and machines used in the explosive method. In both cases, these machines work under the protection of a temporary support - the length of which can be as much as 16 meters. Figure 11 shows the model of cooperation of the temporary mechanized support enclosure with a roadheader. All machines and basic devices of the roadway complex (1 to 5) are located under the support, successively moving forward as the gallery face is being drilled. Behind the support, the LP (8) final steel arc lining is installed. You can use readymade solutions of work platforms with manipulators $(6,7)$. The Department of Mining, Dressing, and Transport Machines has developed its own concept of such a platform with a manipulator (Fig. 12), moving on a rail suspended under a previously made LP steel arc lining. The platform is equipped with a hydraulic manipulator, the construction of which allows for both lifting the lining elements from the floor as well as their movement and assembly into the ready arches of the lining [6].

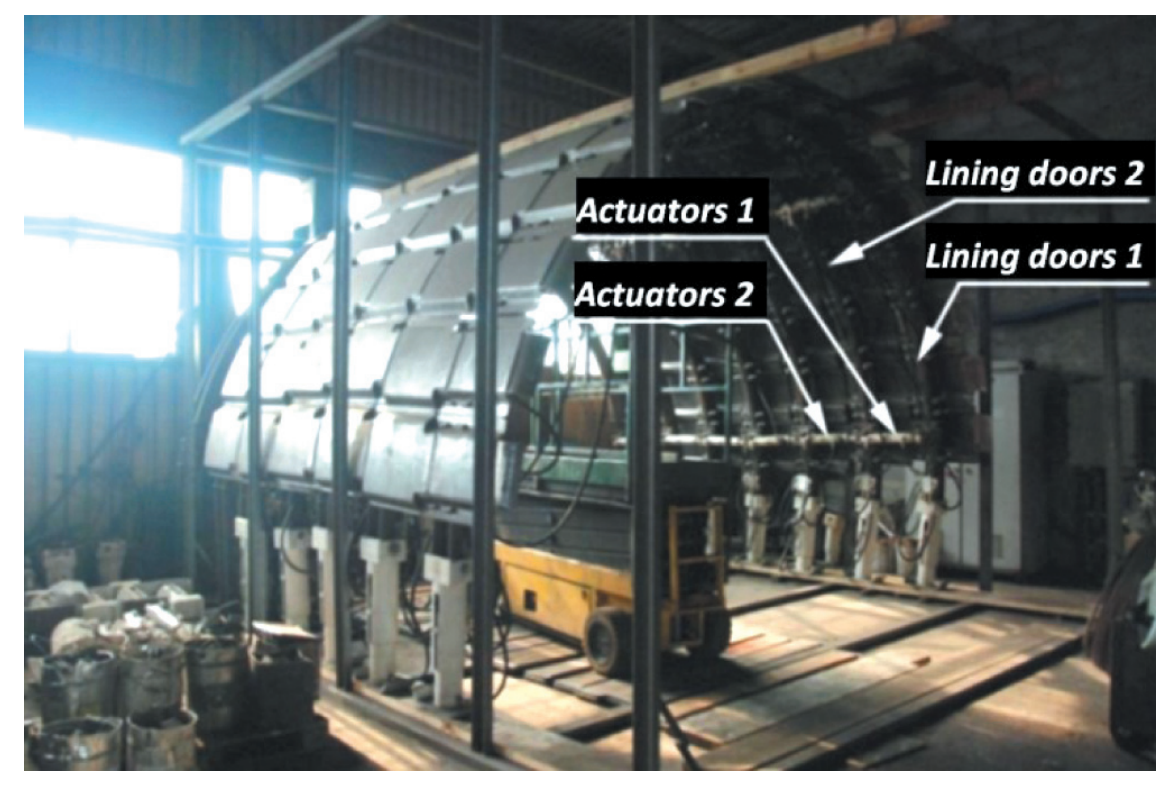

Fig. 10. View of mechanized temporary roadway support before field tests 


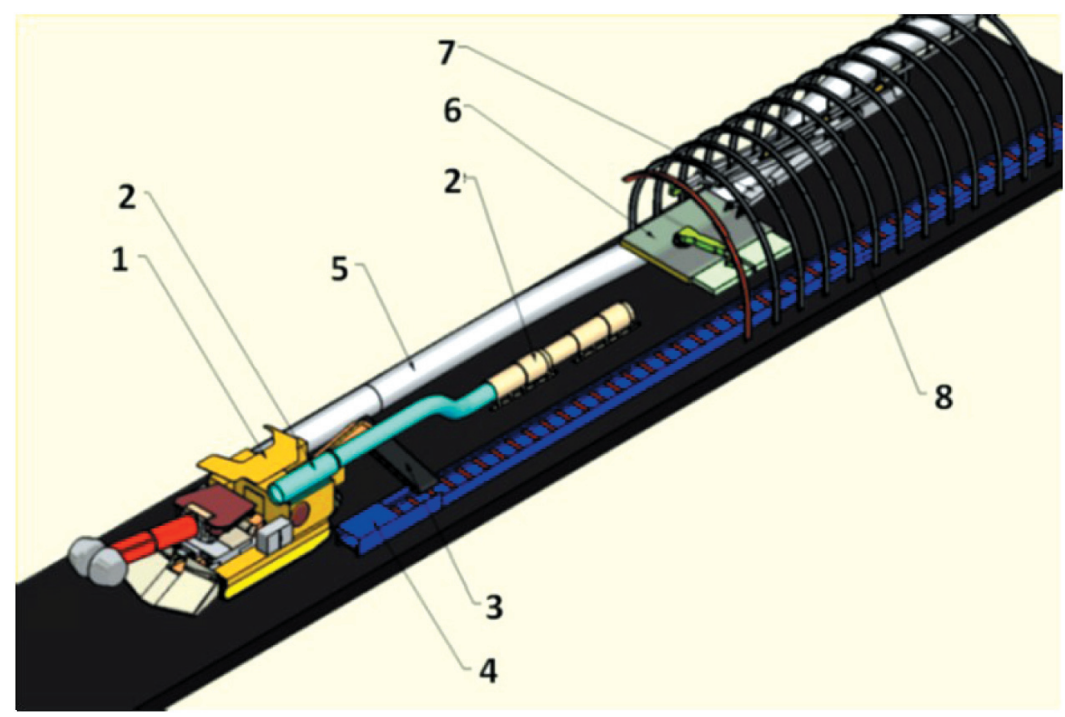

Fig. 11. Model of collaboration of mechanized temporary roadway support with roadheader: 1 - roadheader, 2 -dust precipitator, 3 - bridge conveyor, 4 - chain conveyor, 5 - ventilation pipe, 6 -working platform, 7 - manipulator, 8 - steel arc lining $L P$

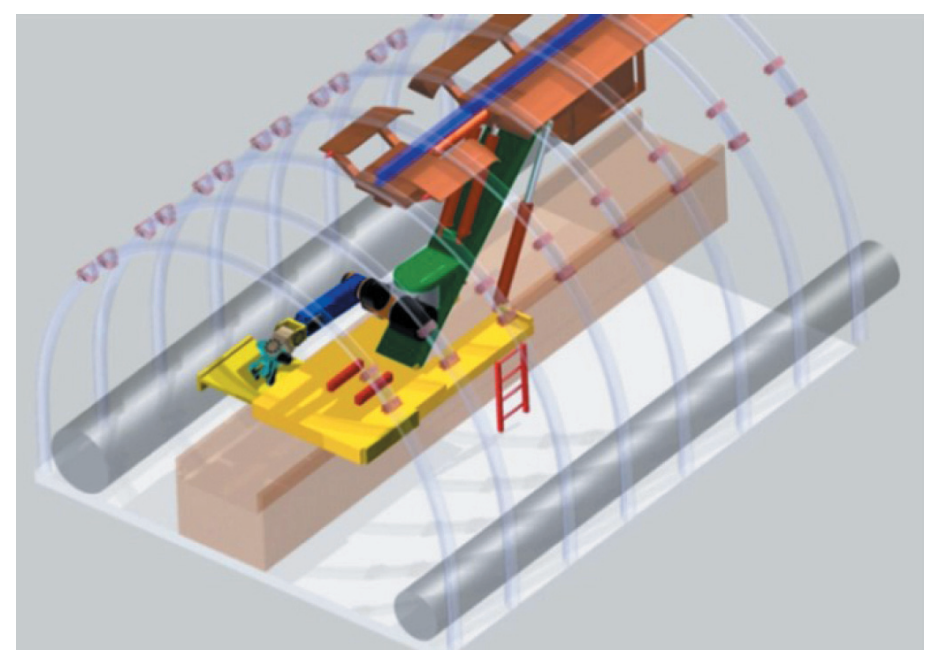

Fig. 12. Concept of working platform with manipulator for final assembly of steel arc lining ŁP [6]

\section{LONGWALL COMPLEX \\ WITH SINGLE-CUTTING HEAD SHEARER USED FOR THIN COAL SEAM EXPLOITATION}

In Poland, underground mine coal covered in thin coal seams constitutes a significant part of the resources, and the low heights of the seams cause a number of limitations affecting the efficiency of coal mining. Currently, coal plows are used for exploiting these thin seams. On the other hand, longwall shearers are considerably less effective when used in thin seams, and the efficiencies are sometimes even several times lower. This is connected with the difficult loading of winning. In the Department of Mining, Dressing, and
Transport Machines, a new solution for a mining machine intended for coal mining in low walls with only one mining head has been developed. The thin-seam shearer fulfills the following requirements that differ from those used so far: separation of the milling process from the loading process, the use of a chain feed system, and the possibility of starting a new cut without the necessity of slotting.

In the scheme in Figure 13, the locations of the individual components of the longwall complex are shown: the mechanized longwall system is equipped with a single cutting head (1), a face armored conveyor (2), a stage loader (4), and a mechanized longwall support (3). The location of the face armored conveyor 
drives (6) and the drive units of the shearer advance (5) decides the location of the driver chain, which is located at the goaf side. The orientation of the shearer advance drives (5) (perpendicular or parallel) is arbitrary [7, 8].

A concept of the single cutting head shearer is shown in Figure 14. The shearer consists of the body (2), a centrally mounted single cutting head (1), and two overhead loaders $(3,4)$. The loader (3) is in the active position, whereas the leader (4) is in the standby position. The shearer is pulled on conveyor troughs (5) with use of the chain (6). The chain (7) is a passive branch for a given velocity.

The diameter of such a shearer is matched to the coal seam thickness, and the selected cutting head has no screw plates. Normally realized by the screw plates, the loading function is now realized by the loaders. Separation of the loading process from the cutting process is one of the major advantages of the presented solution. During longwall shearer operation, its kinematic parameters can be increased without risks related to the problems of loading material onto a conveyor, which was the major factor limiting the output increase. The loading of the winning onto the conveyor is executed by the loader (which is assembled after the direction change), whereas the second loader is set into operational position.

The shearer moves traditionally along the conveyor; however, the chain advance system (which is realized via drive units located in the roadways) is applied. Such a solution allows for a considerable decrease in the shearer's overall dimensions, as the drive units are removed from the shearer body. Moreover, in the case of a break down, the shearer can be pulled away into the roadway, which eliminates the necessity of entering the longwall (i.e., repairs executed in limited space).

The determined geometrical and kinematic parameters of the single cutting head longwall shearer, face armored conveyor, and longwall mechanized support allowed for the development of the preliminary project of the longwall complex in question (as well as its 3D in model the program Autodesk Inventor) (Fig. 15). The longwall shearer system consists ofa single cutting head shearer (1), a face armored conveyor (2), a mechanized section of the longwall support (3), and a stage loader. At both ends of the longwall conveyor, its drive (5) and drive (6) of the shearer are mounted.

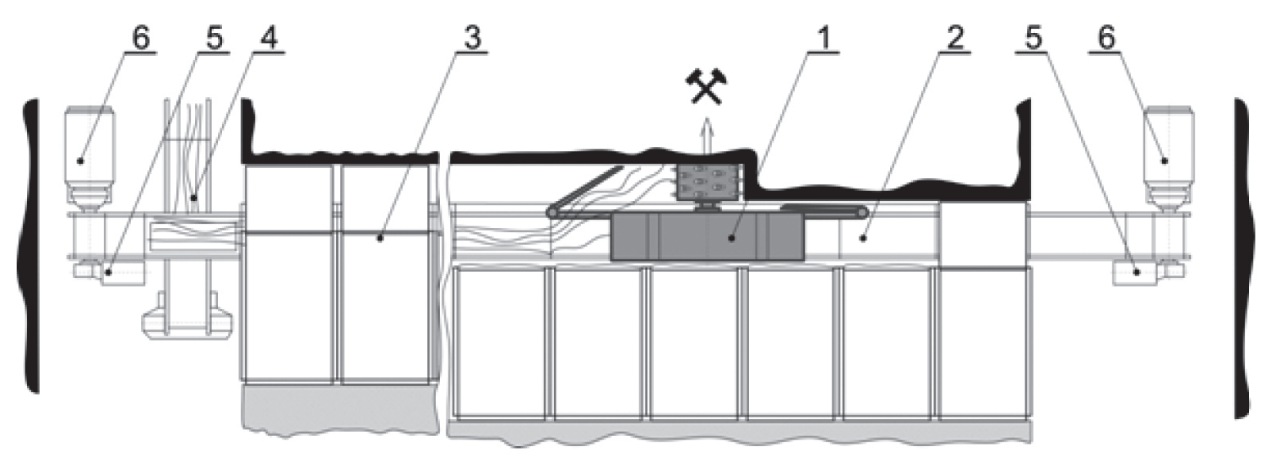

Fig. 13. Scheme of mechanized longwall system equipped with single cutting head shearer [7]

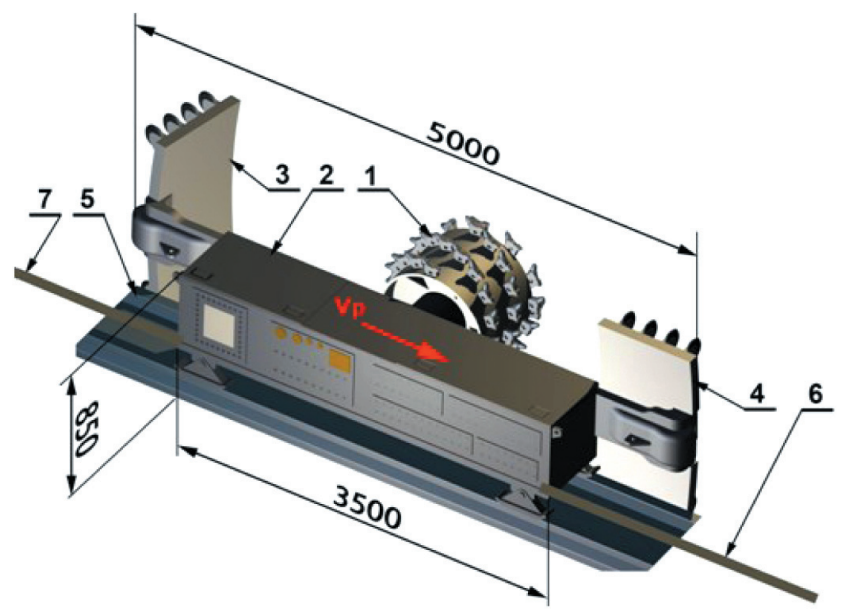

Fig. 14. Concept of single cutting head longwall shearer [7] 


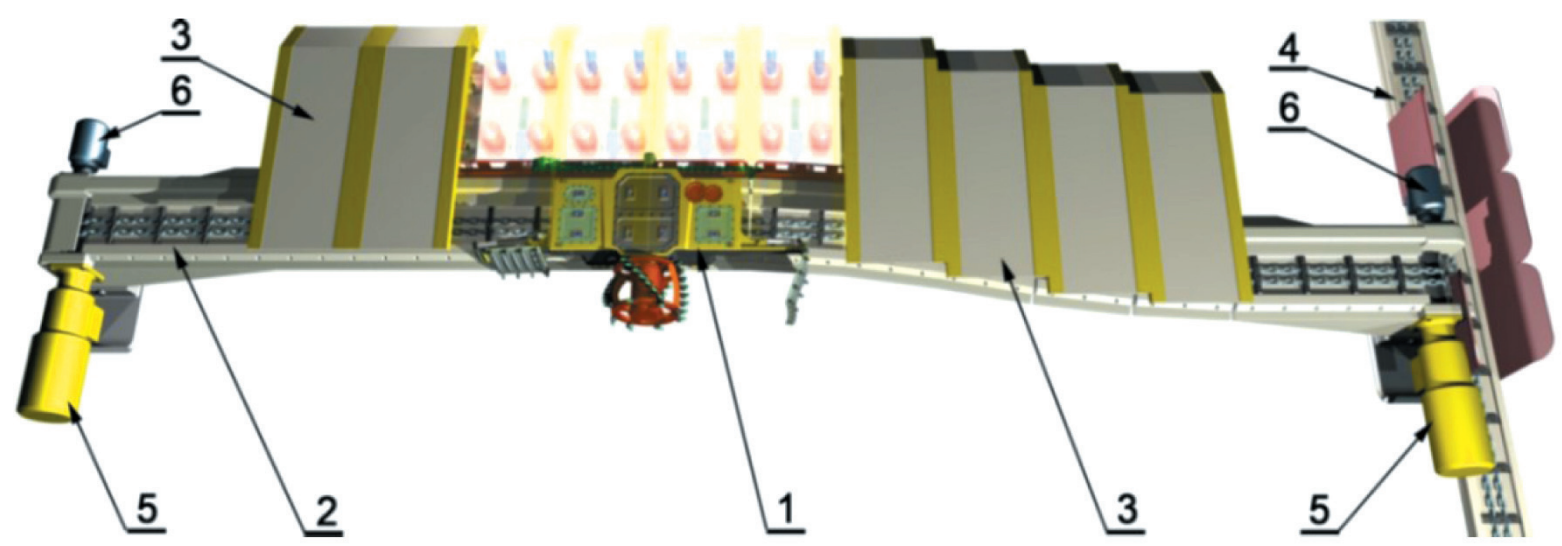

Fig. 15. Model of mechanized longwall system equipped with single cutting head shearer [5]

The shearer body is designed in such a manner that there is enough space for a $2 \times 120 \mathrm{~kW}$ drive unit for the cutting head (according to actual solution reviews) together with a planetary gear, safety devices, a lubrication system, and a water cooling system. Besides the driving devices, a hydraulic system powered from the cutting head drive as well as automation, control, and diagnostic systems are provided. The hydraulic system assures a change in the loader's position and is also used for a shearer shifting along the slippers. The size of the individual elements was selected taking into account the shape and size of the actually used subassemblies of the longwall shearers and coal plows.

The designed system of the thin coal seams exploitation equipped with a single cutting head shearer is designed for two-way mining operation technology. A lack of a slotting phase and full web mining on the whole longwall length are major characteristic features of the technology in question. Cutting head replacement in the case of a seam thickness change is possible, and the control system of machine operation is operated via corrective servo motors.

\section{INNOVATIVE MINING AND HAULING SYSTEM FOR SHAFT SHEARER}

Shaft drilling technology in Poland is based primarily on the blasting method; however in the LGOM district, it is also made with a special technology that uses mechanical rock mining with strengths up to $35 \mathrm{MPa}$. In this case, the mining machine used in the KDS-2 shaft shearer is the KWB-6 longwall shearer arm adapted for this purpose (equipped with one milling worm organ mounted with radial picks). The prevalent mining and geological conditions in the drilled shafts enforce the use of freezing the rock mass. The KDS-2 shaft shearer is adapted to cooperate with various types of equipment installed in the shaft face (and with a grab loader in particular). The process of shaft drilling consists of mining the bottom of the shaft using a milling worm organ and loading the output with a grab loader. The properties of the excavated rock mass and the technology of the organ's operation (vertical axis of its rotation Fig. 16) make it difficult to cut the bottom of the shaft due to its sticking. Therefore, breaks are required to clean the mining head body as well as output the loading during the operation of the shearer [9].

Taking this under consideration, the Department of Mining Machines proposed the concept of a new generation of a shaft complex that will carry out the following processes in parallel. Mining is implemented as a continuous process by the milling mining head attached to the working platform in a way that allows for mining the entire bottom of the shaft. The loading and output haulage are carried out continuously by the scooping (plowshare loader) and a set of belt and bucket conveyors. Temporary supporting of the side walls with steel panels is realised at the same time using integrated hydraulic cylinders. This complex is designed for shaft drilling with a diameter of 8.5-9.5 m. The developed concept utilizes the construction proposed by ITG KOMAG (the spreading system and arm of the mining head). The shaft complex model developed on the basis of this concept is shown in Figure 17 [10]. 


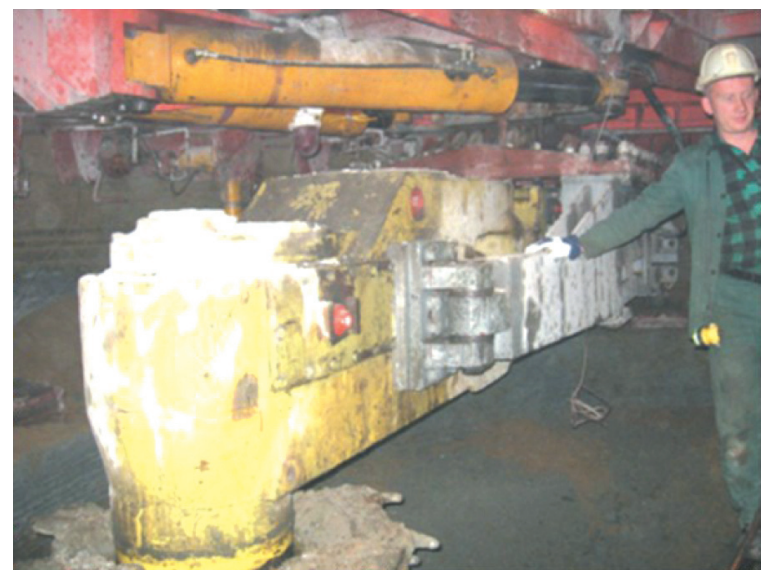

Fig. 16. View of suspension boom of mining head drive system together with head and mining cutter in KDS-2 shaft shearer [9]

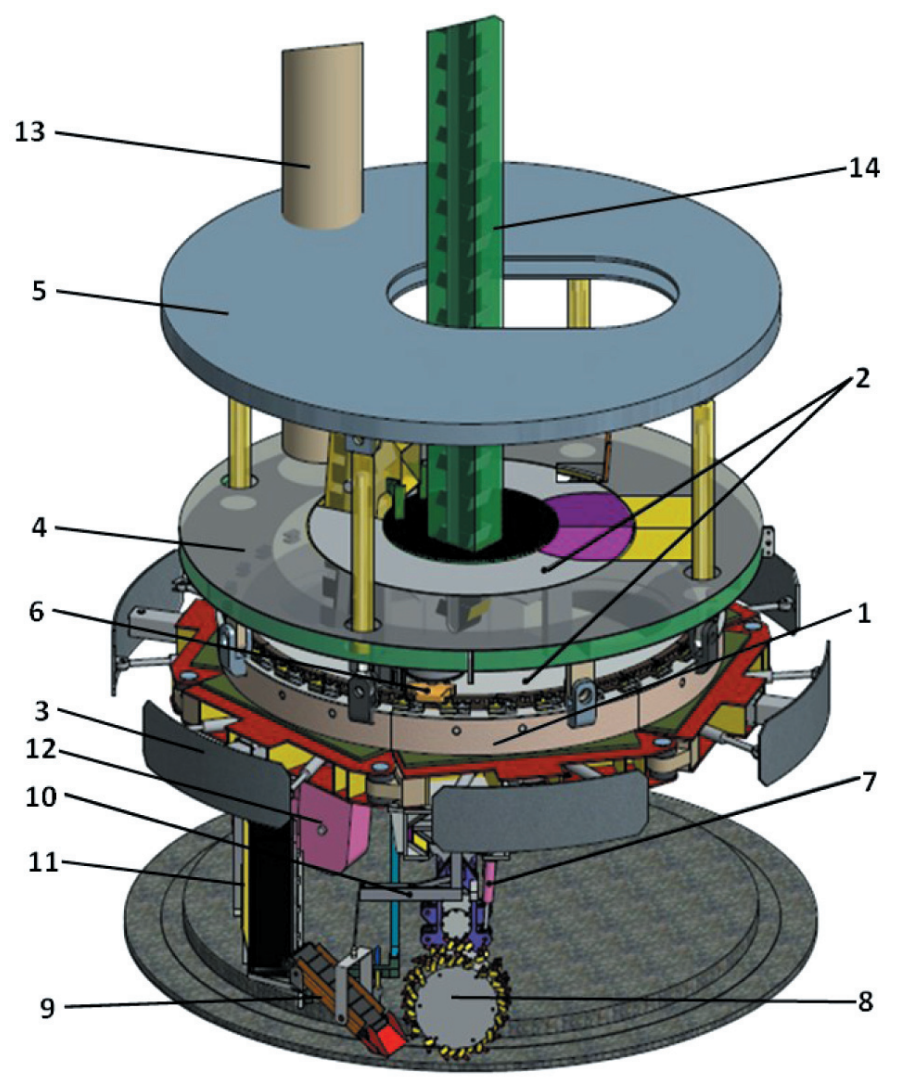

Fig. 17. Model of developed shaft complex [10]: 1 - working platform, 2 - rotary ring, 3 - expanding system, 4- fixed working platform, 5 - permanent working platform, 6 - drive of working platform rotation, 7 - actuators for arm lifting, 8 - milling mining head, 9 - short belt conveyor, 10 - actuators for short belt conveyor lifting, 11 - linear belt conveyor, 12 - overflow and short bucket conveyor, 13 - ventilation pipe-line, 14 - long bucket conveyor

An innovative solution for a shaft shearer is a mining and loading unit (Fig. 18). The mining unit includes a longwall shearer arm with a mining head, two arm lift cylinders, and a lifting system of a short conveyor with a mining head arm. The shearer arm is an adapted arm of the longwall shearer with a milling mining head driven by a $250 \mathrm{~kW}$ motor. The mining head slotting takes place by means of two cylinders placed on one side of the arm. When slotting, the platform rotating ring rotates at the working speed.

During the rotation of the platform rotating ring, the mining head makes cuts with a rectangular crosssection and width equal to the web of the mining head and the height equal to the depth of the mining. After one cut, the mining head is lifted; then, the platform rotary ring returns to the starting position. 


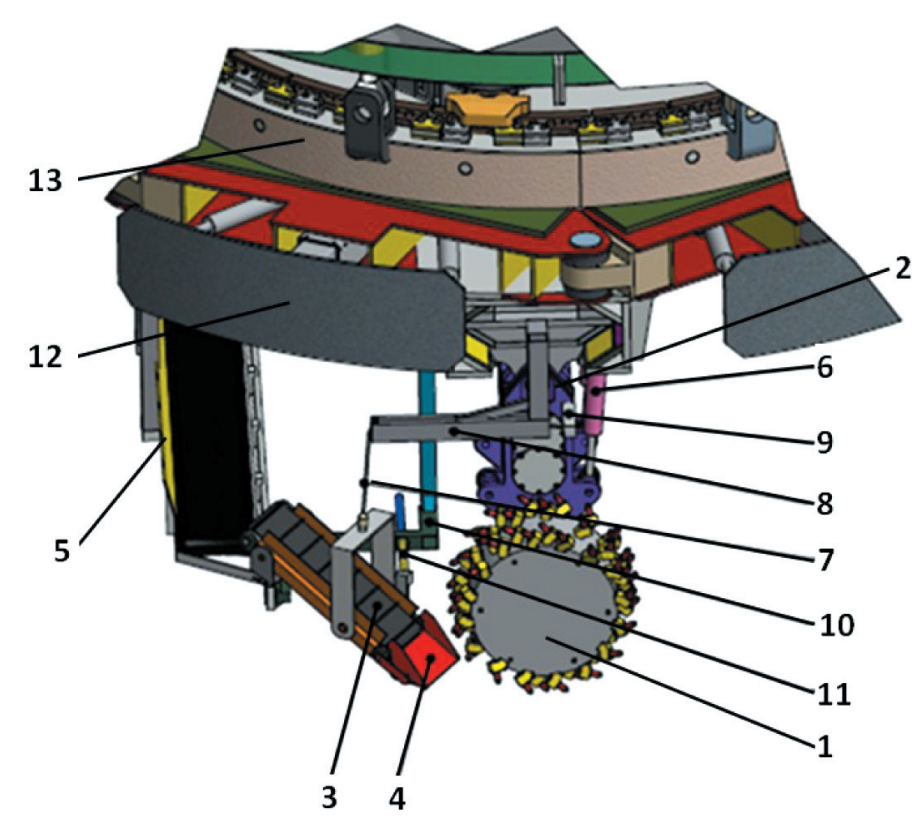

Fig. 18. Model of innovative mining and loading device developed for shaft complex [10]: 1 - milling mining head, 2 -arm, 3 -short belt conveyor, 4 - scraper, 5 - linear belt conveyor, 6 - actuators for arm lifting, 7 - steel rope, 8 - actuators for short belt conveyor lifting, 9 - rope fixing, 10 - conveyor moving system, 11 - conveyor rotation actuator, 12 - expanding system, 13 - rotary ring

It is necessary to slot the mining head in the new section; i.e., in a new position, towards the axis of the shaft, with the value of the mining head web. During the slotting for subsequent cuts, the mining head moves along the linear guide in the direction of the shaft axis simultaneously with the rotation of the ring, which results in the spiral movement of the body until it reaches the position in the new cutting. The execu- tion of subsequent cuts takes place in the same way until the whole shaft bottom layer is mined (Fig. 19). During the phase of slotting and normal mining, the short belt conveyor moves behind the mining head and hauls the output to the horizontal (linear) belt conveyor [11].

The conveyor set is the last "link" of the closed operation of the shaft shearer. Through the scraper

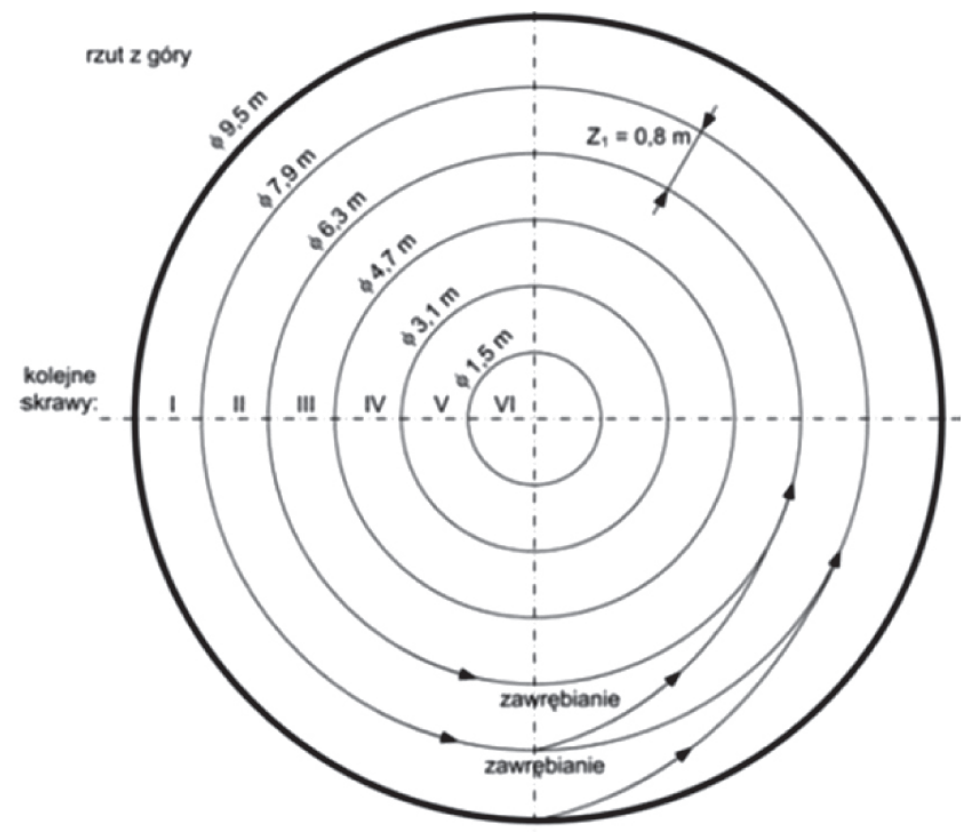

Fig. 19. Diagram of technology of making subsequent cuts of bottom of shaft [11] 
and short belt conveyor, the output from the mining head is loaded onto the horizontal belt conveyor and then moved to the dumping unit. From the dumping unit, the output is removed by a short bucket conveyor and transported to the output bunker. From the output bunker, the bucket conveyor hauls the output outside the working platform to a height set by the user. The short conveyor is lifted by means of a steel cable connected through a lifting system between the shearer's arm and a short conveyor belt. An actuator has also been introduced to allow the short belt conveyor to straighten (relative to the horizontal conveyor) during the passage of the mining head arm to the center of the shaft.

At the same time, the presented shaft complex carries out the process of mining, loading, and hauling the output from the bottom of the shaft. The cutting width of the mining head was set at $0.8 \mathrm{~m}$ (with an acceptable value of $1.0 \mathrm{~m}$ ). According to the adopted assumptions, the mining takes place by means of the milling mining head with the horizontal axis. Before starting the mining, the working platform with the shearer is set at such a distance from the bottom of the shaft so that the organ can make a web at a depth of $0.3 \mathrm{~m}$ (maximum $-0.35 \mathrm{~m}$ ). The slotting takes place by means of the pivoting arm of the mining head. When lowering the work platform, the long bucket conveyer is also lowered. After establishing and spreading the working platform, the slotting phase takes place. During the slotting, the platform rotary ring performs a rotational movement with the working speed. During the rotation of the platform rotating ring the milling mining head makes a toroidal shape with a rectangular cross-section of the width equal to the width of the mining head. After making one cut, the organ is lifted, and the platform rotary ring returns to the starting position. Then, it is necessary to slot the mining head in the new cut; i.e., in a new position towards the axis of the shaft by the value of the mining head web (as shown in Figure 19). During the phase of the excavation and normal mining, the plowshare loader moves behind the mining head and loads the output to the conveyor assembly. The long bucket conveyor haulage the output outside the working platform to the required height resulting from the equipment used in the shaft complex. After making the full shaft bottom layer, the organ returns to the initial position, and the next cut is made with a 0.3 meter depth by leaving the platform with the shearer.
The presented shaft shearer differs from the complexes available on the market as well as those known from the literature. It is characterized by a modular structure with wide modification possibilities, which translates into many variants adapted to different working conditions, needs, and requirements of the user and coexisting in the excavation of the machines and devices.

\section{SUMMARY}

The machine and equipment solutions presented in this article are the result of research carried out at the Department of Mining, Dressing, and Transport Machines. They are innovative solutions that are not currently encountered in Polish mining. Some of them have already been successfully subjected to field testing, while the remaining solutions are currently at the stage of preliminary project preparation (with the implementation of prototypes on this basis). It can be forecasted that, in the near future, several of the solutions presented in the article may be successfully used in Polish underground mining.

\section{References}

[1] Kotwica K., Gospodarczyk P., Stopka G., Kalukiewicz A.: The designing process and stand tests of a new solution of a mining head with disc tools of complex motion trajectory for compact rocks mining, "Quarterly Mechanics and Control" 2010, 29, 3: 119-129.

[2] Kotwica K., Gospodarczyk P., Stopka G., Puchała B., Słowiński A.: Wyniki prób poligonowych głowicy urabiającej nowej generacji z narzędziami dyskowymi o złożonej trajektorii ruchu, "Przegląd Górniczy" 2011, 11: 31-36.

[3] Kotwica K., Gospodarczyk P., Stopka G.: A new generation mining head with head with disc tool of complex trajectory, "Archives of Mining Sciences" 2013, 58, 4: 985-1006.

[4] Kotwica K., Krauze K., Wydro T.: Zastosowanie tymczasowej obudowy zmechanizowanej $w$ procesie drażenia wyrobisk korytarzowych, "Zeszyty Naukowe Politechniki Śląskiej” 2007, 1765, 280: 311-325.

[5] Krauze K., Bołoz Ł., Wydro T.: Prototype of temporary mechanized mine roadway support of the dog headings. Theory and technique of coal mining and disaster prevention in deep mines, in: Proceedings of international mining conference, Anhui University of Science and Technology, China, 2014: 538-545.

[6] Krauze K., Bołoz Ł., Wydro T.: Urządzenie do montażu tukowej obudowy podatnej w podziemnych wyrobiskach korytarzowych, Opis zgłoszeniowy wynalazku, PL 412667 A1, "Biuletyn Urzędu Patentowego", 2016: 33.

[7] Bołoz Ł.: Unique project of single-cutting head longwall shearer used for thin coal seams exploitation, "Archives of Mining Sciences" 2013, 58, 4: 1057-1070. 
[8] Krauze K., Bołoz Ł.: Model jednoorganowego frezującego kombajnu ścianowego, "Napędy i Sterowanie" 2010, 12: 120-123.

[9] Kotwica K., Krauze K., Bołoz Ł., Twardak E.: Wpływ warunków górniczo-geologicznych $w$ drążonym szybie na prace organu urabiajacego kombajnu szybowego, in: Problemy bezpieczeństwa $w$ budowie $i$ eksploatacji maszyn i urządzeń górnictwa podziemnego, red. K. Krauze, Centrum Badań i Dozoru Górnictwa Podziemnego, Katowice-Lędziny 2010: 134-146.

[10] Krauze K., Bołoz Ł., Wydro T., Mucha K.: Kompleks szybowy nowej generacji, in: Mechanizacja, automatyzacja i robotyzacja w górnictwie. T. 2: Problemy eksploatacji i zarządzania w górnictwie podziemnym i odkrywkowym, red. K. Krauze, CBiDGP Lędziny-Kraków 2017: 103-112.
[11] Krauze K., Bołoz Ł., Wydro T.: Zmechanizowany frezujący kompleks szybowy, IV Polski Kongres Górniczy, Kraków 2017: 105-106.

KRZYSZTOF KRAUZE, prof. KRZYSZTOF KOTWICA, prof. Department of Mining, Dressing and Transport Machines

Faculty of Mechanical Engineering and Robotics AGH University of Science and Technology al. Mickiewicza 30, 30-059 Krakow, Poland \{krauze, kotwica\}@agh.edu.pl 


\title{
Innowacyjne rozwiązania maszyn górniczych opracowane w Katedrze Maszyn Górniczych, Przeróbczych i Transportowych Akademii Górniczo-Hutniczej
}

\begin{abstract}
Eksploatacja surowców mineralnych metodami podziemnymi staje się coraz trudniejsza ze względu na warunki górniczo-geologiczne, w jakich te surowce zalegaja. Wiąze się to z głębokościa zalegania i miąższościa eksploatowanych pokładów, trudniej urabialnymi skałami oraz warunkami klimatycznymi. Drażenie wyrobisk udostępniających $i$ przygotowawczych, a także prowadzenie eksploatacji $w$ takich warunkach wymaga specjalnie do tego opracowanych i wykonanych maszyn. W Katedrze Maszyn Górniczych, Przeróbczych $i$ Transportowych AGH w Krakowie w ostatnich latach opracowano szereg innowacyjnych rozwiąań, które moga być zastosowane do maszyn i urzadzeń pracujących $w$ ciężkich warunkach górniczo-geologicznych. $W$ niniejszym artykule przedstawiono wybrane rozwiazania: głowice z narzędziami dyskowymi niesymetrycznymi o złożonej trajektorii ruchu dla kombajnów chodnikowych, tymczasowa, zmechanizowana i kroczaca obudowę chodnikowa, unikalny kompleks ścianowy dla niskich pokładów z kombajnem weglowym jednoorganowym oraz innowacyjny uktad urabiania i odstawy do mechanicznego drązenia szybów z wykorzystaniem kombajnów szybowych.
\end{abstract}

Słowa kluczowe: innowacyjne rozwiazania, maszyny górnicze, urabianie, wydajność, bezpieczeństwo

\section{WSTĘP}

Warunki górniczo-geologiczne, w jakich zalegają w Polsce surowce mineralne eksploatowane metodami podziemnymi, stają się coraz trudniejsze. Wiąże się to z większymi głębokościami ich zalegania, warunkami klimatycznymi, a także coraz trudniej urabialnymi skałami. Powoduje to, że obecnie stosowane technologie udostępniania i wybierania kopalin są coraz bardziej zawodne lub nie pozwalają na osiągnięcie zadowalającej wydajności. Aby zaradzić temu problemowi, w Katedrze Maszyn Górniczych, Przeróbczychi Transportowych już od wielu lat prowadzone są próby konstruowania maszyn i urządzeń, które będą w stanie wydajnie pracować w trudnych warunkach górniczych.

W pierwszej kolejności opracowano i wykonano kilka unikalnych, nie tylko w skali kraju stanowisk badawczych, na których prowadzono badania nad zasto- sowaniem nowych narzędzi urabiających i technik urabiania skał zwięzłych. Są to między innymi stanowiska do badania procesu urabiania skał pojedynczymi narzędziami (rys. 1a), urabiania skał narzędziami dyskowymi (rys. 1b) i urabiania skał organami frezującymi ślimakowymi (rys. 1c).

Wyniki przeprowadzonych na tych stanowiskach badań, przykładowo pokazane na rysunku 2, pozwoliły na opracowanie nowych narzędzi i głowic urabiających, które mogą zostać wykorzystane podczas urabiania skał zwięzłych i bardzo zwięzłych. Najbardziej obiecującym kierunkiem jest wykorzystanie w procesie urabiania skał mininarzędzi dyskowych symetrycznych i niesymetrycznych oraz tak zwanej techniki tylnego podcinania. Technika ta - w porównaniu z techniką frezowania lub statycznego miażdżenia pozwala na zmniejszenie energochłonności procesu urabiania i zwiększenie granulacji urobku. 
a)

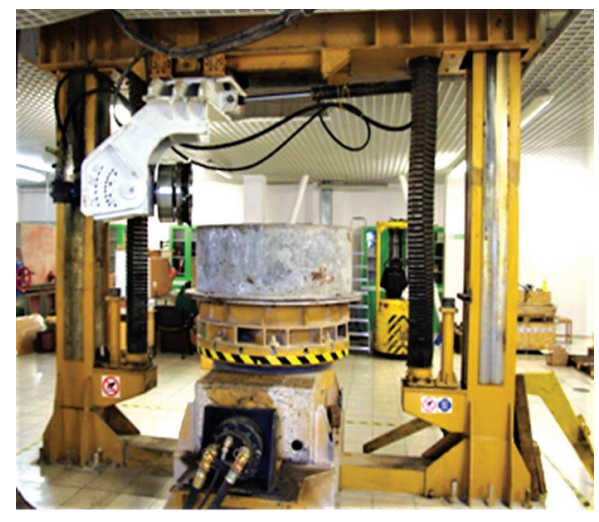

b)

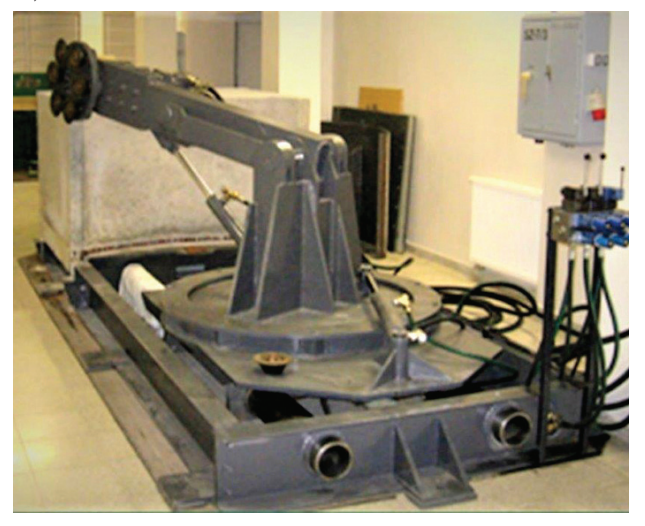

c)

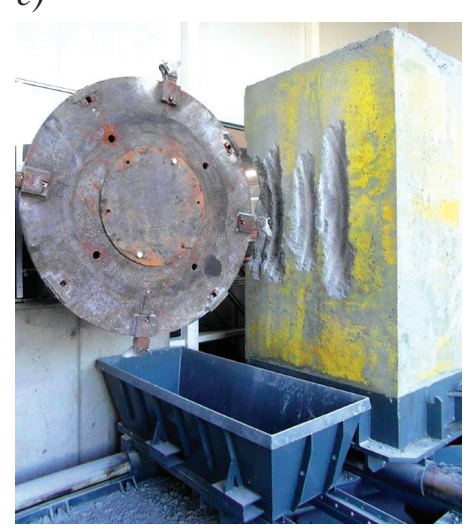

Rys. 1. Stanowiska badawcze do badania procesu urabiania skat: a) pojedynczymi narzędziami; b) narzędziami dyskowymi; c) organami frezującymi ślimakowymi

a)

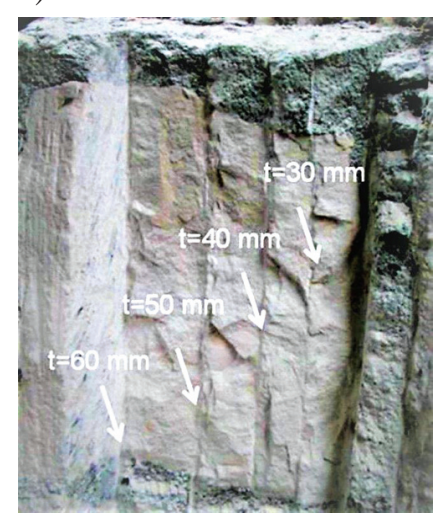

b)

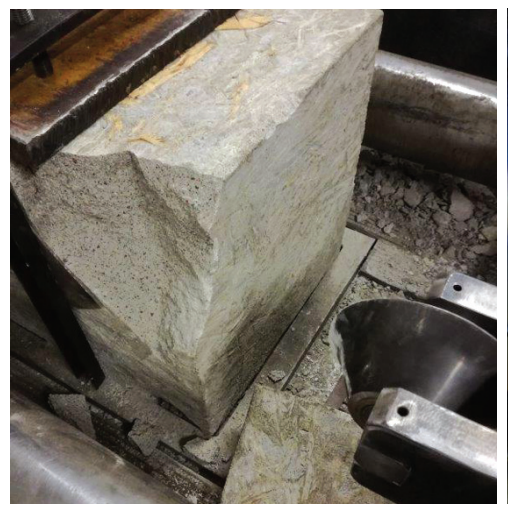

c)

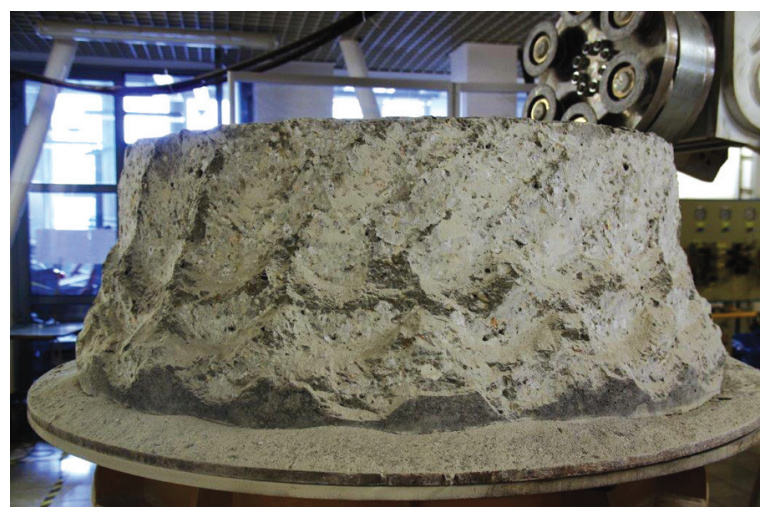

Rys. 2. Wyniki badania procesu urabiania skat z wykorzystaniem: a) pojedynczej tarczy z narzędziami dyskowymi w ruchu prostym; b) pojedynczego narzędzia dyskowego; c) pojedynczej tarczy z narzędziami dyskowymi w ruchu złożonym

Wykorzystując natomiast doświadczenia uzyskane podczas realizacji prac badawczych w przemyśle wydobywczym, zaproponowano opracowanie nietypowych oraz innowacyjnych rozwiązań maszyn, które można zastosować przy eksploatacji niskich pokładów węgla, drążeniu korytarzowych wyrobisk przygotowawczych i udostępniających, a także szybów. Wyniki tych prac prowadzonych w Katedrze MGPiT zostały zaprezentowane w niniejszym artykule.

\section{GŁOWICA URABIAJACA DO KOMBAJNÓW CHODNIKOWYCH O ZŁOŻONEJ TRAJEKTORII RUCHU}

W polskim górnictwie bardzo duża liczba wyrobisk korytarzowych drążona jest metodami mechanicznymi z wykorzystaniem ramionowych kombajnów chodnikowych, wyposażonych w organy frezujące. Stosowane na tych organach narzędzia - noże styczno-obrotowe, w niekorzystnych warunkach górniczo-geologicznych lub przy nieprawidłowych warunkach pracy, ulegają przyspieszonemu zużyciu. Wpływa to na prędkość i koszty drążenia wyrobisk. W Katedrze MGPiT zaproponowano więc wykorzystanie na organach urabiających mininarzędzi dyskowych niesymetrycznych. Narzędzia te wykorzystuje się w technice mechanicznego urabiania skał nie tylko jako narzędzia zgniatające, ale również jako narzędzia odłupujące. Zasadą techniki podcinania jest urabianie skały przez odcinanie jej w kierunku wolnej powierzchni.

Narzędzie dyskowe działa na skałę stycznie do powierzchni urabianej calizny, podobnie jak to ma miejsce w przypadku narzędzia skrawającego, jednak odmienność tej metody polega na wykorzystaniu ruchu obtaczania dysku, co eliminuje skutecznie tarcie ślizgowe na rzecz tarcia tocznego. Wykorzystanie narzędzi dyskowych w ten sposób obniża zużycie energii i wartość siły docisku, co daje możliwości konstrukcji maszyny urabiającej o odpowiednio mniejszej mocy i mniejszej masie własnej niż w przypadku klasycznych dysków miażdżących, działających w kierunku prostopadłym do powierzchni urabianej calizny [1-3]. 
$\mathrm{Na}$ podstawie analizy stanu techniki światowej i wyników badań własnych w Katedrze MGPiT opracowano nową koncepcję organu, w którym ruch narzędzi dyskowych jest wymuszony i powoduje urabianie calizny skalnej narzędziami dyskowymi po złożonej trajektorii. Pozwala to na przecinanie się linii urabiania poszczególnych narzędzi oraz ułatwienie urabiania skał zwięzłych przez wyłamywanie bruzd skalnych. Zmniejsza to energochłonność procesu urabiania. W tym celu zabudowano narzędzia dyskowe na oddzielnych tarczach, zamontowanych obrotowo na płaszczu organu urabiającego i napędzanych niezależnie od niego. Projekt i model nowego rozwiązania głowicy z narzędziami dyskowymi o złożonej trajektorii wykonano we współpracy z Zakładami REMAG S.A (obecnie FAMUR S.A.). Założono opracowanie i przystosowanie nowego rozwiązania głowicy dla produkowanego przez REMAG S.A. kombajnu chodnikowe- go KR 150. Na podstawie analizy głowic frezujących wykorzystywanych w tym kombajnie założono, że długość nowego rozwiązania nie powinna przekraczać $1750 \mathrm{~mm}$, jej średnica $860 \mathrm{~mm}$, a masa 5 t. Opracowany model głowicy zakładał zabudowanie na jego kadłubie trzech tarcz z ośmioma narzędziami dyskowymi. Kadłub płaszcza miał możliwość niezależnego obrotu względem tarcz z narzędziami dyskowymi. Możliwości kinematyczne nowego rozwiązania głowicy przedstawiono na rysunku 3, a jej model pokazano na rysunku $4[1,3]$.

Na podstawie opracowanego modelu sporządzono projekt techniczny i wykonano egzemplarz głowicy przeznaczony do zabudowy na kombajnie KR 150 i prób poligonowych w zakładach REMAG S.A. Próby te wykonano na wielkogabarytowym bloku betonowym o wytrzymałości na jednoosiowe ściskanie $R_{c}$ około $80 \mathrm{MPa}$.
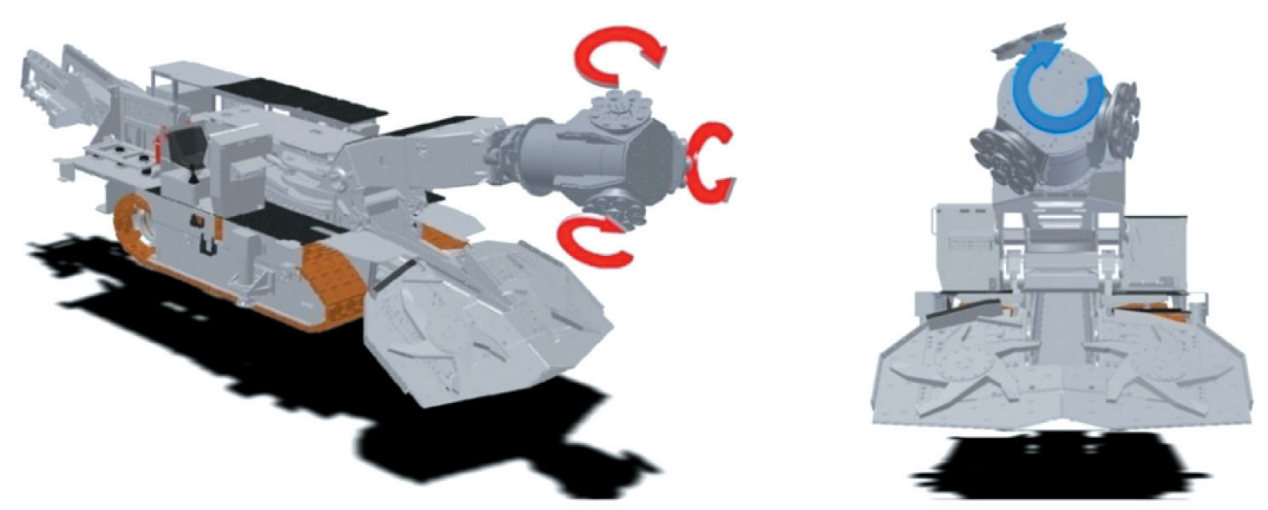

Rys. 3. Możliwości kinematyczne nowego rozwiązania głowicy zabudowanej na kombajnie chodnikowym KR 150 [3]

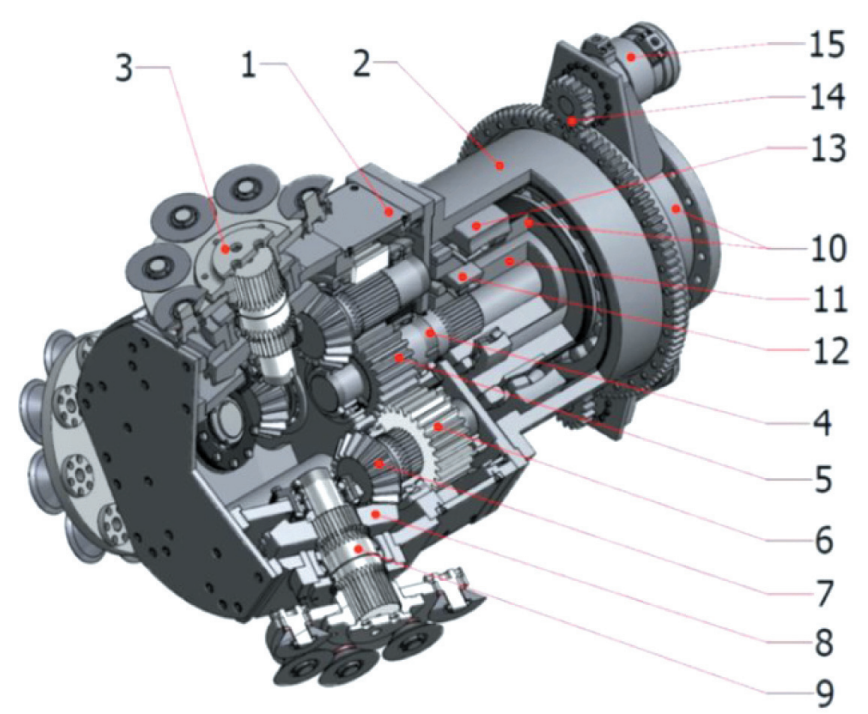

Rys. 4. Model nowego rozwiązania głowicy z narzędziami dyskowymi o złożonej trajektorii [3]: 1 - przekładnia główna, 2 - przekładnia pomocnicza, 3 - tarcza dyskowa, 4-wał wejściowy, 5 - koło zębate centralne, 6 - koło zębate orbitalne, 7 -zębnik, 8 - koło talerzowe, 9 - wat wyjściowy, 10 - wspornik, 11 - tącznik, 12 i 13 - łożyska, 14 - przekładnia korpusu, 15 - silnik hydrauliczny 
Najkorzystniejsze efekty pracy - duże uziarnienie urobku, małe obciążenie silników napędowych oraz ograniczone drgania, uzyskano dla prędkości obrotowej kadłuba głowicy około $201 / \mathrm{min}$, przy wartości prędkości obrotowej tarcz około 60 1/min i obrotach kadłuba głowicy przeciwnych do ruchu wskazówek zegara oraz obrotach tarcz z narzędziami dyskowymi zgodnymi z ruchem wskazówek zegara.

W przypadku takich parametrów pracy głowicy nie stwierdzono większych oznak zużycia narzędzi dyskowych. Widok uzyskanego urobku i charakterystycznej powierzchni (przecinających się linii skrawania) urobionego bloku pokazano na rysunku 5.

Zwiększenie prędkości obrotowej tarcz z narzędziami dyskowymi powodowało wzrost zapylenia, a przy prędkości maksymalnej występowało nawet iskrzenie przy kontakcie narzędzi z urabianą próbką. Natomiast zmiana kierunku obrotów kadłuba głowicy lub tarcz z narzędziami dyskowymi na przeciwny miała negatywny wpływ na wartość obciążenia silników oraz zużywanie się zarówno narzędzi dyskowych, jak i samych tarcz.

Zużywanie się tarcz z narzędziami dyskowymi wyeliminowano, wprowadzając modyfikacje konstrukcji tych tarcz. W miejsce płaskich i okrągłych tarcz zabudowano tarcze $\mathrm{w}$ kształcie kwiatu, $\mathrm{z}$ zewnętrznymi elementami odchylonymi pod kątem około $-15^{\circ}$. Widok takiej zmodyfikowanej tarczy pokazano na rysunku 6a. W dalszych próbach nie stwierdzono już zużywania się tarcz. Do kolejnych badań opracowano tarczę i uniwersalny uchwyt narzędzia dyskowego, który miał pozwolić na mocowanie dysku w co najmniej trzech pozycjach w wyniku jego skręcenia w płaszczyźnie przechodzącej przez oś tarczy. Jako najkorzystniejszą przyjęto wersję z wymiennym monoblokiem dla trzech ustawień dysku względem tarczy pod kątem $-5^{\circ}, 45^{\circ}$ i $90^{\circ}$ względem osi tarczy. Na rysunku $6 \mathrm{~b}$ przedstawiono widok tarczy dyskowej z monoblokami w wersji umożliwiającej mocowanie narzędzi dyskowych prostopadle do osi tarczy, czyli pod kątem $90^{\circ}$.

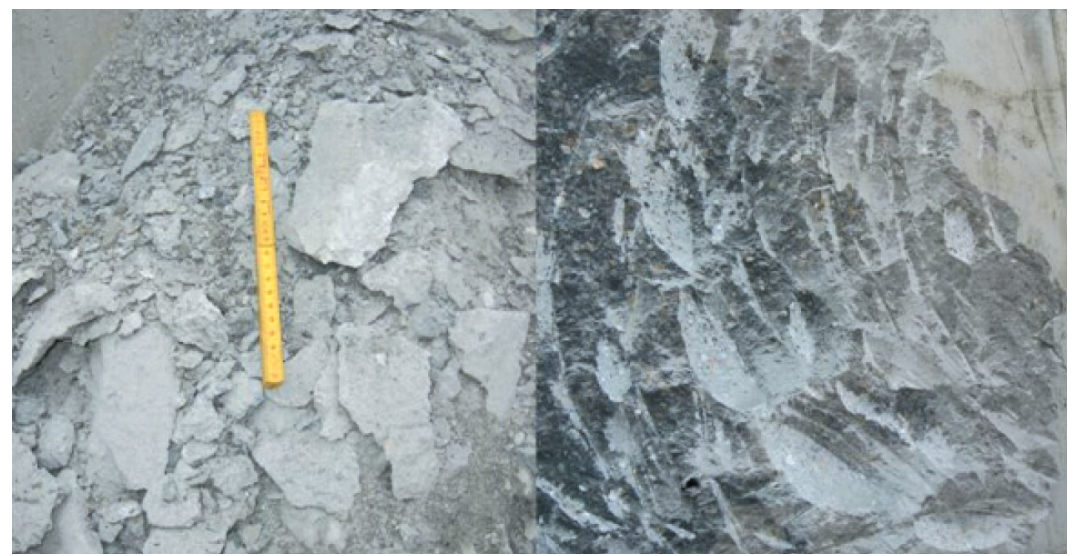

Rys. 5. Widok urobku i powierzchni urabianej próbki uzyskanych podczas prób urabiania głowica z narzędziami o złożonej trajektorii ruchu [2]

a)

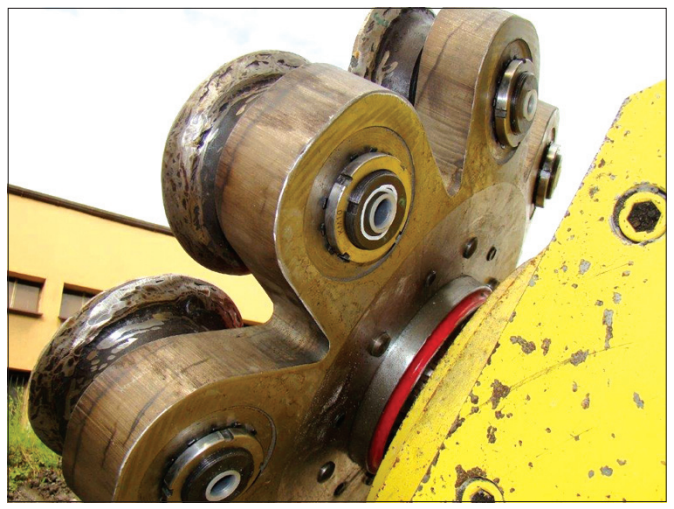

b)

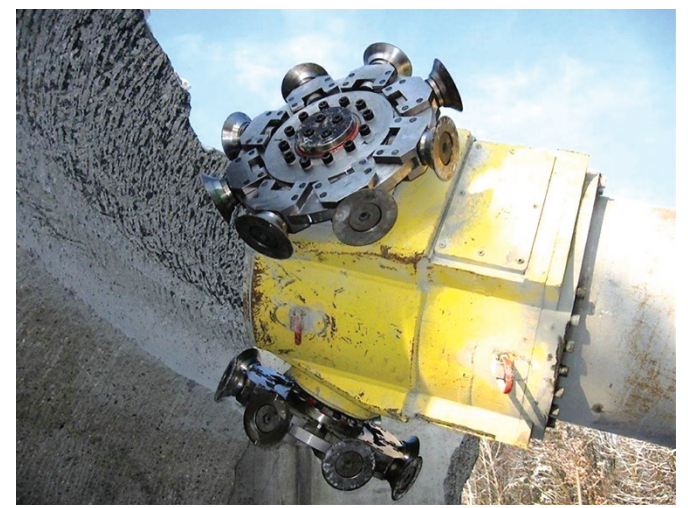

Rys. 6. Widok: a) zmodyfikowanego rozwiazania tarczy z narzędziami dyskowymi mocowanymi pod katem $-5^{\circ}$; b) nowego uniwersalnego rozwiąania tarczy z narzędziami dyskowymi mocowanymi w wymiennych uchwytach pod katem $90^{\circ}$ [2] 
Przeprowadzone próby urabiania przy zamocowaniu narzędzi dyskowych pod kątem $-5^{\circ}, 45^{\circ}$ i $90^{\circ}$ względem osi tarczy wykazały jednak, że ustawienie narzędzi pod kątem innym niż $-5^{\circ}$ do $-15^{\circ} \mathrm{w}$ bardzo krótkim czasie skutkuje poważnymi ich uszkodzeniami w postaci wykruszeń i wyłamań krawędzi narzędzi. Dlatego w następnych próbach mocowano narzędzia dyskowe tylko w uchwytach pod kątem $-5^{\circ}$. Nie powiodły się także próby zamontowania w miejsce narzędzi dyskowych gładkich, narzędzi zbrojonych na obwodzie słupkami z węglików spiekanych. Również po bardzo krótkim okresie pracy narzędzia te uległy poważnemu uszkodzeniu - duża liczba słupków z węglika została wyłamana. Widok po próbach urabiania narzędzi montowanych pod kątem $90^{\circ}$ i uzbrojonych słupkami z węglików spiekanych, w porównaniu do dysków gładkich mocowanych pod kątem $-5^{\circ}$, pokazano na rysunku 7.

a)

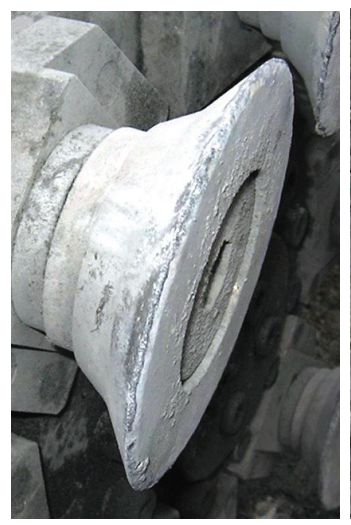

b)

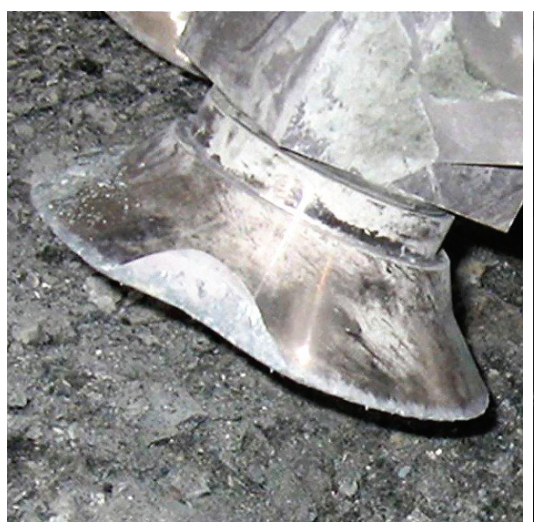

Nowe rozwiązanie głowicy zostało dostosowane do montażu na ramieniu kombajnu chodnikowego FR 250 (rys. 8) o większej mocy i masie własnej, produkcji FAMUR S.A., a przeprowadzone próby urabiania bloku betonowego wykazały, że ten kombajn bardziej nadaje się do zastosowania głowicy dyskowej niż kombajn KR 150. Głowica pracowała o wiele stabilniej.

Zaproponowane rozwiązanie głowicy z narzędziami dyskowymi niesymetrycznymi o złożonej trajektorii ruchu wykazało swoją przydatność podczas urabiania skał zwięzłych i może zostać wykorzystane jako alternatywa dla głowic frezujących kombajnów chodnikowych ramionowych. Dla uzyskania najkorzystniejszych parametrów pracy głowicy - duże uziarnienie urobku, małe obciążenie silników napędowych oraz ograniczone drgania, konieczne jest jednak dobranie odpowiedniej konfiguracji kierunku i prędkości obrotowej kadłuba głowicy i tarcz z narzędziami.

c)

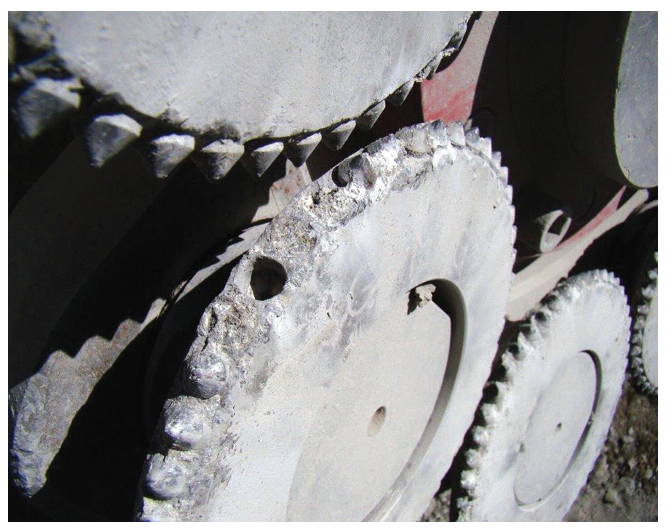

Rys. 7. Widok zużycia po próbach urabiania narzędzi dyskowych: a) zamontowanych pod katem $-5^{\circ}$; b) zamontowanych pod kątem $90^{\circ}$; c) uzbrojonych stupkami z węglików spiekanych [2]

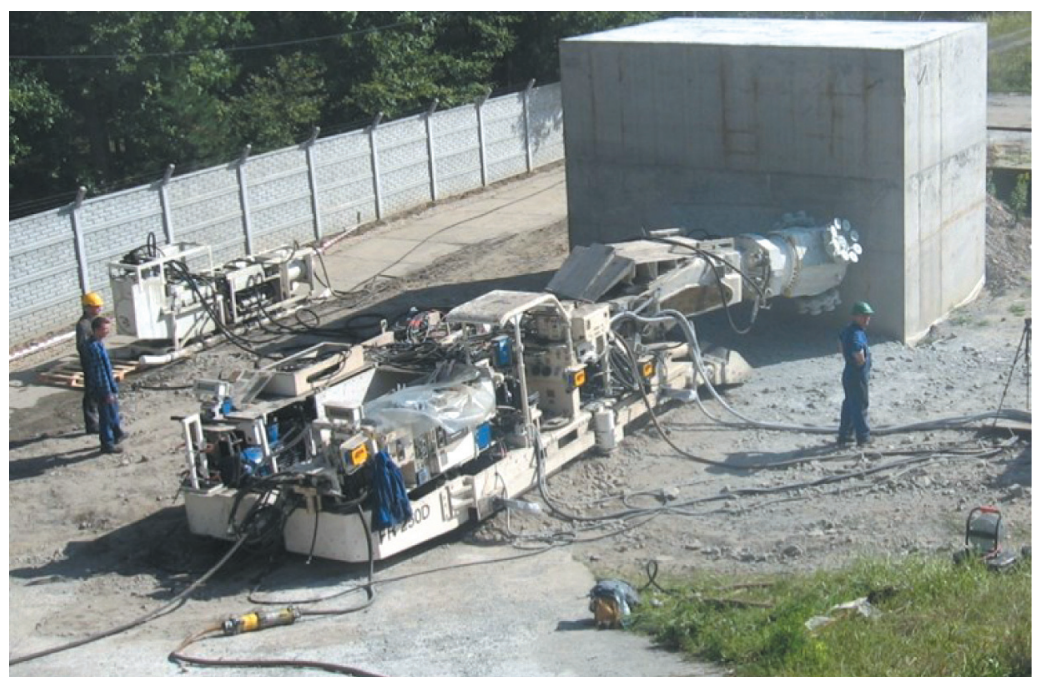

Rys. 8. Widok głowicy urabiającej z narzędziami dyskowymi zamontowanej na kombajnie FR 250 podczas prób poligonowych 
Jednak konieczne jest przeprowadzenie dalszych prób w celu opracowania technologii jej pracy podczas drążenia wyrobisk korytarzowych.

Na podstawie wyników przeprowadzonych prób poligonowych stwierdzono także, że dla efektywnego urabiania i trwałości narzędzi dyskowych bardzo ważny jest sposób ich ustawienia względem tarcz oraz materiał, z jakiego zostały one wykonane. Najkorzystniejsze jest ustawienie ich tak, aby oś obrotu tych narzędzi była nachylona pod kątem w zakresie od $-5^{\circ}$ do $-15^{\circ}$ względem osi obrotu tarcz. Sugerowane jest także uwzględnienie w przyszłym rozwiązaniu głowicy układu automatycznego sterowania ramienia dla zapewnienia jego płynnego przemieszczania się.

\section{TYMCZASOWA, KROCZACA, ZMECHANIZOWANA OBUDOWA CHODNIKOWA}

W procesie drążenia wyrobisk korytarzowych, bez względu na zastosowaną w nim metodę drążenia (strzelanie MW lub urabianie mechaniczne) jedną z dłuższych w czasie operacji jest zabudowa wyrobiska. Często pochłania ona nawet do 40\% ogółu czasu przeznaczonego na drążenie wyrobiska. Zmniejszenie czasu tej operacji jest możliwe np. przez zastosowanie zmechanizowanych platform roboczych, pozwalających na zmontowanie dużych elementów obudowy poza przodkiem i przetransportowanie ich po zakończeniu urabiania. W Katedrze MGPiT postanowiono wrócić do pomysłów realizowanych w latach 80. ubiegłego wieku, czyli zmechanizowanych, tymczasowych obudów chodnikowych. Pozwala to na pracę maszyn pod stropem zabezpieczonym taką obudową, a równolegle za nią realizowany jest proces stawiania obudowy ostatecznej. Stosowane wtedy obudowy nie miały dużych możliwości dostosowania się do zmiennych parametrów geometrycznych chodnika, a ponadto ich cykliczne rozpieranie i rabowanie wpływało niekorzystnie na stan stropu [4].

W Katedrze MGPiT założono, że obudowa taka będzie dostosowana do współpracy zarówno z kombajnem chodnikowym, jak i maszynami stosowanymi w metodzie tradycyjnej - strzelanie MW. Ponadto będzie miała możliwość zwiększania swojej długości w wyniku dodawania modułowych segmentów do $16 \mathrm{~m}$, a za nią będzie stawiana obudowa stalowa łukowa typu ŁP. Inną różnicą będzie rabowanie na czas przemieszczania obudowy elementów spągowych i przesuwanie obudowy w kontakcie ze stropem. Na podstawie powyższych założeń opracowano wstępną koncepcję tymczasowej zmechanizowanej obudowy chodnikowej. Została ona zaprojektowana jako konstrukcja modułowa, z możliwością dodawania lub odejmowania poszczególnych segmentów [4, 5]. Widok zestawu składającego się z sześciu segmentów przedstawiono na rysunku 9.

Obudowa składa się z dwóch odrzwi skrajnych (1) oraz czterech identycznych odrzwi wewnętrznych (2). Łuki w dolnej, prostej części wyposażone są w siłowniki rozpierania o skoku $300 \mathrm{~mm}$ (3), przy czym nominalny wymiar obudowy uzyskuje się przy wysunięciu tych siłowników o $150 \mathrm{~mm}$, a pozostałe $150 \mathrm{~mm}$ jest w rezerwie. Poszczególne segmenty są połączone ze sobą czterema siłownikami przesuwu (4). Ze względu na sposób pracy siłowniki te przy skrajnych odrzwiach

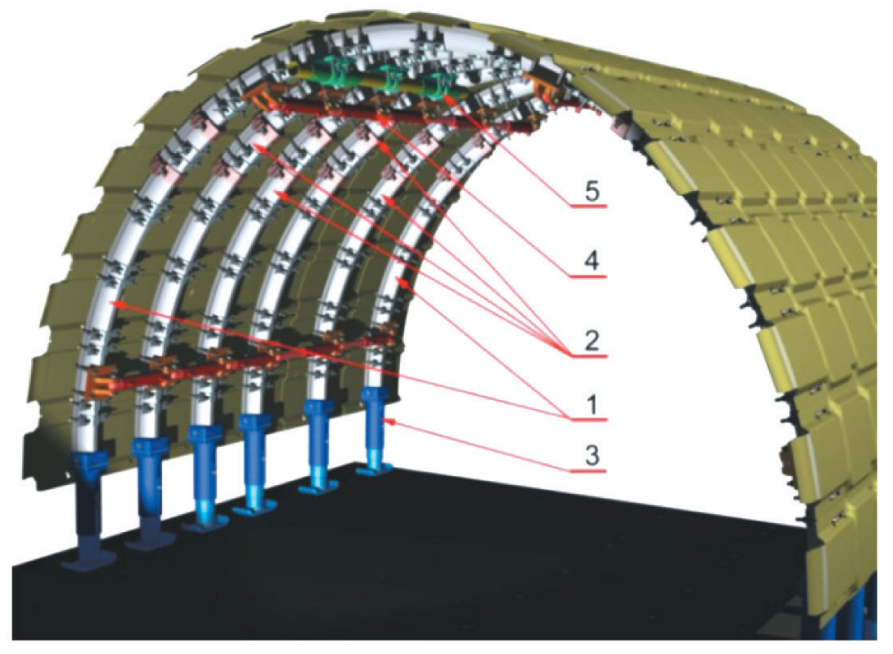

Rys. 9. Model tymczasowej zmechanizowanej obudowy chodnikowej [9]: 1 - odrzwia skrajne, 2 - odrzwia wewnętrzne, 3 - siłowniki rozpierania, 4 - siłowniki przesuwu, 5 - prowadzenia rurowe 
są siłownikami dwustronnego, a pozostałe jednostronnego działania. Dodatkowo łuki połączone są prowadzeniami rurowymi (5) zapewniającymi ich stateczność podczas rabowania. Poza tym znaczna część powierzchni odrzwi pokryta jest specjalną wykładką, która została zaprojektowana w taki sposób, aby osłaniała wyrobisko przed rumoszem skalnym i była elementem prowadzącym, a także umożliwiała mocowanie blach montażowych oraz wszelkiego rodzaju osprzętu na łukach.W przedstawionej koncepcji zmechanizowana obudowa tymczasowa jest przystosowana do drążenia wyrobisk o przekrojach dostosowanych do obudowy ŁP 9 i ŁP 10 . Przesuw jednego zestawu względem drugiego wynosi $280 \mathrm{~mm}$ i wynika z przyjętego skoku siłowników przesuwu. Podziałka, czyli odległość pomiędzy poszczególnymi segmentami w czasie pracy, przy wysuniętych siłownikach przesuwu, wynosi $900 \mathrm{~mm}$ [5].

Po zabudowie zestawu obudowy na długość uwarunkowaną typem maszyny lub maszyn do urabiania i ładowania można rozpocząć cykl jej pracy. W miarę postępu przodka chodnika poszczególne segmenty obudowy rabowane są przez zsunięcie siłowników umieszczonych $\mathrm{w}$ stopach podporowych, począwszy od czoła przodka i przemieszczane za pomocą siłowników przesuwu do przodu. Po przesunięciu segmentu jest on ponownie rozpierany, a następnie jest realizowane sekwencyjne przesuwanie pozostałych segmentów obudowy aż do ostatniego. Ze względu na stosunek zabioru do skoku siłownika przesuwu zakłada się sterowanie w jednym cyklu po dwa lub trzy odrzwia. Do prawidłowego zrealizowania tej operacji konieczne było opracowanie i wykonanie układu sterowania dla poszczególnych odrzwi obudowy.
Na podstawie opracowanego projektu w zakładach Hydromel wykonano prototyp sześcioelementowej tymczasowej zmechanizowanej obudowy chodnikowej wraz z układem zasilania i sterowania (rys. 10). Podczas prób stanowiskowych obudowa ta realizowała poprawnie wszystkie założone czynności. Dalsza część prób została zrealizowana w ZG Janina w Libiążu w warunkach dołowych. Również te próby nie wykazały większych problemów podczas pracy nowej obudowy. Jedynie należy dopracować hydrauliczny układ zasilania i sterowania pod kątem jego zautomatyzowania, obecnie sterowanie realizowane jest ręcznie.

Jak nadmieniono, obudowa przystosowana jest do współpracy zarówno z kombajnami chodnikowymi, jak i maszynami wchodzącymi w skład kompleksu do drążenia metodami strzałowymi. W obu przypadkach maszyny te pracują pod ochroną obudowy tymczasowej, której długość może wynosić nawet $16 \mathrm{~m}$. Na rysunku 11 pokazano model współpracy tymczasowej zmechanizowanej obudowy chodnikowej z kombajnem chodnikowym. Wszystkie maszyny i urządzenia podstawowe kompleksu (od 1 do 5) znajdują się pod sukcesywnie przemieszczającą się w miarę drążenia chodnika obudową. Za obudową realizowany jest montaż obudowy ostatecznej stalowej łukowej ŁP (8). Można do tego wykorzystać gotowe rozwiązania platform roboczych z manipulatorami $(6,7)$. W Katedrze MGPiT opracowano własną koncepcję takiej platformy $\mathrm{z}$ manipulatorem (rys. 12), przemieszczającej się na szynie podwieszonej pod wcześniej wykonaną obudową ŁP. Na platformie zabudowany jest hydrauliczny manipulator, którego konstrukcja umożliwia zarówno podnoszenie elementów obudowy ze spągu, jak i ich przemieszczanie i montaż w gotowych łukach obudowy [6].

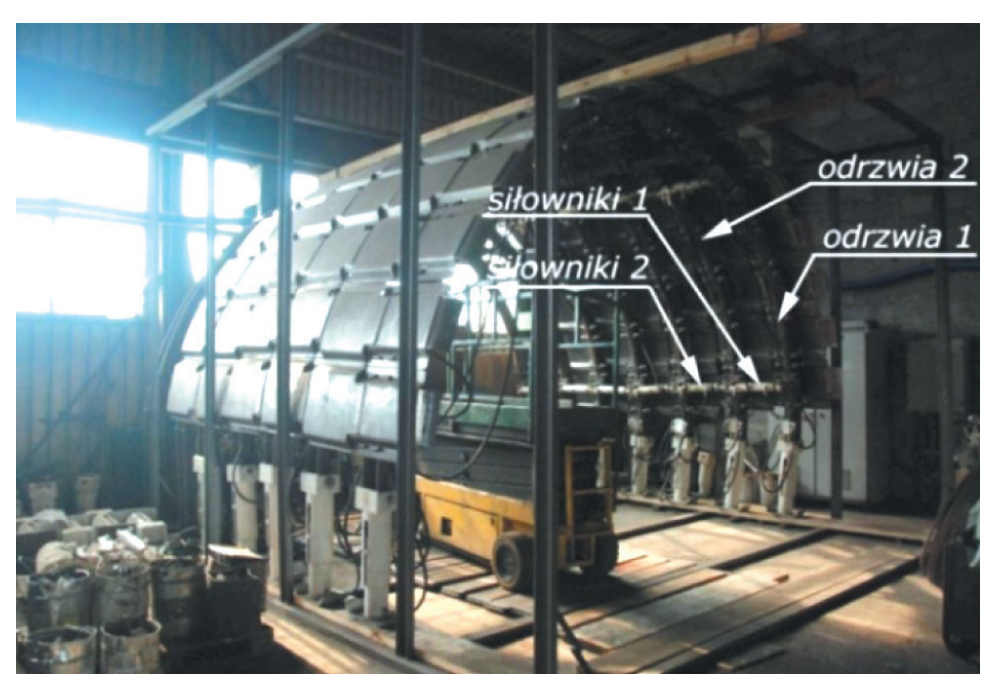

Rys. 10. Widok prototypu tymczasowej zmechanizowanej obudowy chodnikowej przed próbami stanowiskowymi 


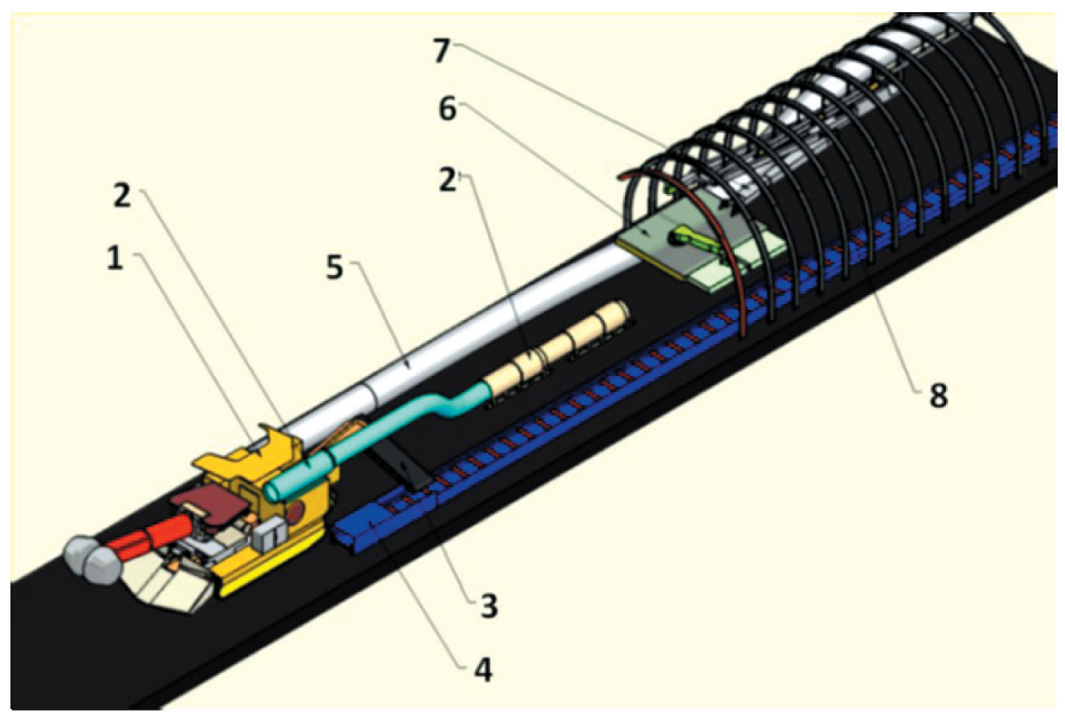

Rys. 11. Model wspótpracy tymczasowej zmechanizowanej obudowy chodnikowej z kombajnem chodnikowym: 1 - kombajn chodnikowy, 2 - odpylacz, 3 - przenośnik mostowy, 4 - przenośnik zgrzebłowy, 5 - lutniociag, 6 - platforma robocza, 7 - manipulator, 8 - obudowa tukowa $€ P$

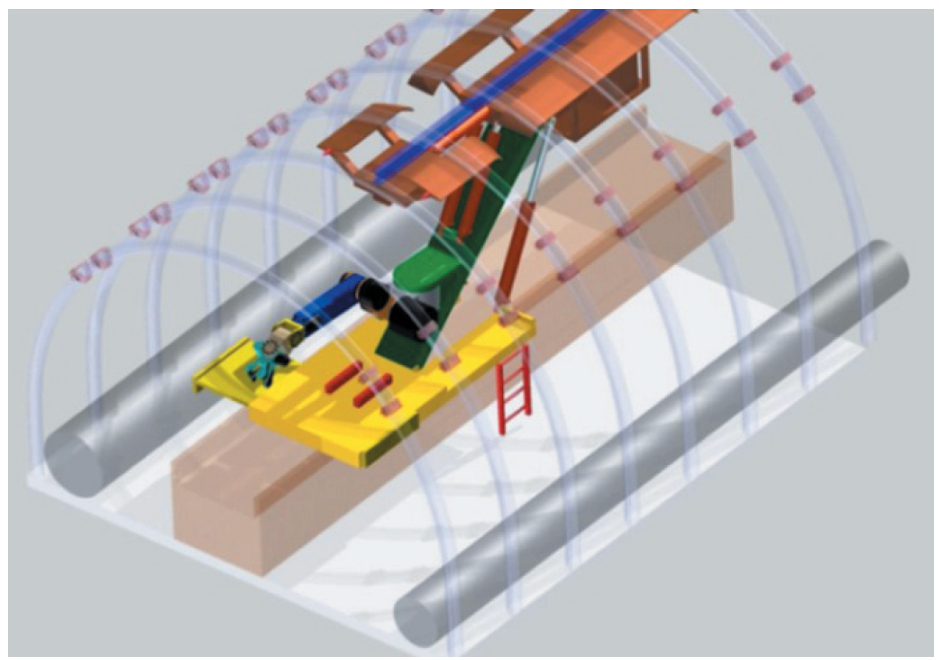

Rys. 12. Koncepcja platformy i manipulatora do zaktadania ostatecznej obudowy tukowej ŁP [6]

\section{KOMPLEKS ŚCIANOWY}

\section{DLA NISKICH POKŁADÓW}

Z KOMBAJNEM WĘGLOWYM JEDNOORGANOWYM

W Polsce węgiel kamienny zalegający w pokładach cienkich o miąższości od $1,0 \mathrm{~m}$ do $1,5 \mathrm{~m}$ stanowi znaczną część zasobów, a niewielka wysokość wyrobiska ścianowego powoduje szereg ograniczeń wpływających na efektywność eksploatacji węgla.

Obecnie do eksploatacji tych pokładów stosowane są głównie strugi węglowe. Natomiast ścianowe kombajny węglowe w przypadku eksploatacji niskich pokładów są zdecydowanie mniej efektywne, uzyskiwane wydajności są czasami nawet kilkakrotnie mniejsze. Związane jest to $\mathrm{z}$ utrudnionym ładowaniem urobku. W Katedrze MGPiT opracowano nowe rozwiązanie maszyny urabiającej przeznaczonej do wydobywania węgla w ścianach niskich tylko z jednym organem urabiającym. Kombajn do eksploatacji cienkich pokładów spełnia następujące wymagania różniące go od dotychczas stosowanych: rozdzielenie procesu frezowania od procesu ładowania, zastosowanie cięgnowego systemu posuwu, możliwość rozpoczynania nowego skrawu bez konieczności zawrębiania. $\mathrm{Na}$ rysunku 13 pokazano na schemacie rozmieszczenie poszczególnych komponentów w kompleksie ścianowym. Kompleks ścianowy wyposażony jest w kombajn 
jednoorganowy (1), ścianowy przenośnik zgrzebłowy (2), podścianowy przenośnik zgrzebłowy (4) oraz zmechanizowaną obudowę ścianową (3). Z usytuowania napędów przenośnika zgrzebłowego (6) oraz napędów posuwu kombajnu (5) wynika miejsce prowadzenia łańcucha napędowego, które znajduje się od strony zrobów. Zorientowanie napędów posuwu kombajnu (5) i przenośnika zgrzebłowego ścianowego (6) - prostopadłe lub równoległe jest dowolne [7, 8].

Zgodnie $\mathrm{z}$ opracowaną koncepcją kombajn ten (rys. 14) składa się z kadłuba (2), jednego zamocowanego centralnie organu urabiającego (1) oraz dwóch rozkładanych ładowarek odkładniowych (3) i (4). Ladowarka (3) znajduje się w pozycji czynnej, natomiast ładowarka (4) w biernej. Kombajn jest ciągnięty po rynnach przenośnika ścianowego (5) za pomocą łańcucha (6) i (7). Średnica organu dla takiego kombajnu dobierana jest do miąższości pokładu. Przy czym zastosowany organ nie ma płatów ślimakowych. Funkcję ładowania, realizowaną zwykle przez płaty, przejmują ładowarki. Rozdzielenie procesu ładowania od procesu frezowania jest jedną z najważniejszych zalet prezentowanego rozwiązania. Podczas pracy w ścianie pręd- kość posuwu kombajnu może być zwiększana bez ryzyka wystąpienia problemów z ładowaniem na przenośnik, co obok możliwości przemieszczania się kombajnisty w niskiej ścianie było głównym czynnikiem hamującym wzrost wydobycia. Załadunek urobku na przenośnik odbywa się za pomocą ładowarki odkładniowej, która po zmianie kierunku urabiania składa się, natomiast druga ustawiana jest w pozycji roboczej. Kombajn porusza się po przenośniku, jednak przy zastosowaniu cięgnowego systemu posuwu, który zrealizowany jest za pomocą napędów znajdujących się w chodnikach. Rozwiązanie takie umożliwia znaczne zmniejszenie gabarytów kombajnu dzięki usunięciu ciągników z kadłuba. Ponadto kombajn w przypadku awarii może zostać wyciągnięty do chodnika, co eliminuje konieczność wchodzenia do ściany i napraw w ograniczonej przestrzeni.

Określone parametry geometryczne i kinematyczne kombajnu jednoorganowego, ścianowego przenośnika zgrzebłowego oraz zmechanizowanej obudowy chodnikowej pozwoliły na opracowanie modelu 3D kompleksu ścianowego w programie Autodesk Inventor (rys. 15).

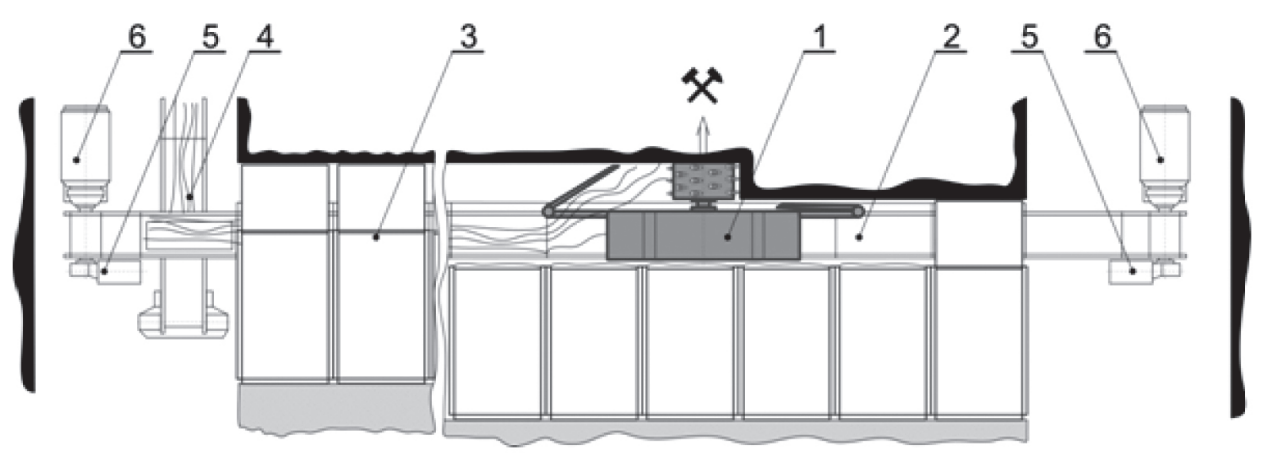

Rys. 13. Schemat zmechanizowanego kompleksu ścianowego wyposażonego w kombajn jednoorganowy [7] (opis w tekście)

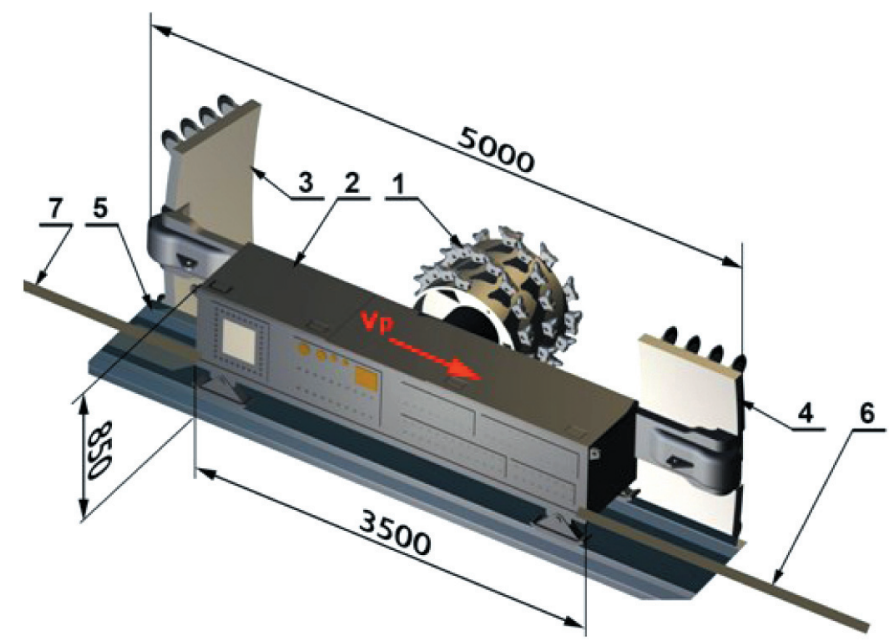

Rys. 14. Koncepcja jednoorganowego kombajnu ścianowego [7] 


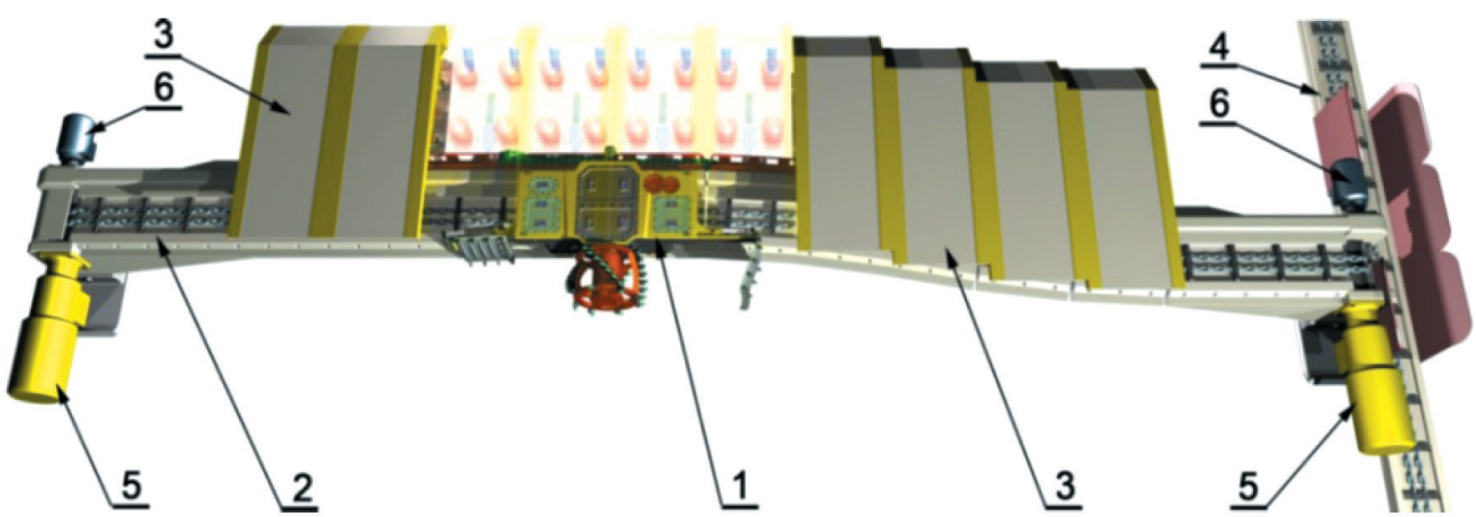

Rys. 15. Model zmechanizowanego kompleksu ścianowego wyposażonego w kombajn jednoorganowy [7]

Składa się on z kombajnu jednoorganowego (1), ścianowego przenośnika zgrzebłowego (2), sekcji zmechanizowanej obudowy ścianowej (3) i podścianowego przenośnika zgrzebłowego (4). Na końcach przenośnika ścianowego znajdują się jego napędy (5) oraz napędy (6) kombajnu. W kadłubie przewidziano umieszczenie jednostki napędowej organu urabiającego o mocy około $2 \times 120 \mathrm{~kW}$. Oprócz jednostki napędowej $\mathrm{w}$ kadłubie przewidziano układ hydrauliczny zasilany z jednostki napędzającej organ, układ automatyki, sterowania i diagnostyki. Układ hydrauliczny potrzebny jest do zmiany położenia ładowarek oraz podnoszenia całego kombajnu na płozach. Wielkości poszczególnych elementów dobrano, uwzględniając kształt i wielkość obecnie stosowanych części kombajnów ścianowych oraz strugów węglowych.

Zaproponowany kompleks do eksploatacji cienkich pokładów wyposażony w kombajn jednoorganowy przeznaczony jest do pracy w technologii urabiania dwukierunkowego. Charakterystyczną cechą tej technologii jest brak fazy zawrębiania oraz praca na pełny zabiór na całej długości ściany. W przypadku zmiany miąższości pokładu możliwa jest zmiana organu, natomiast sterowanie w kierunku wybiegu odbywać się będzie za pomocą siłowników.

\section{INNOWACYJNY UKŁAD URABIANIA I ODSTAWY DLA KOMBAJNÓW SZYBOWYCH}

Technologia drążenia szybów w Polsce oparta jest przede wszystkim na metodzie strzałowej, ale w okręgu LGOM wykonywane są one także specjalną technologią wykorzystującą urabianie mechaniczne skał o wytrzymałości do $35 \mathrm{MPa}$. Zastosowana w tym przy- padku w kombajnie szybowym KDS-2 maszyna urabiająca jest adaptowanym do tego celu ramieniem kombajnu ścianowego KWB-6, wyposażonym w jeden frezujący organ ślimakowy, zbrojony nożami promieniowymi. Warunki górniczo-geologiczne panujące w drążonych szybach wymuszają stosowanie mrożenia górotworu. Kombajn szybowy KDS-2 przystosowany jest do współpracy z różnymi rodzajami urządzeń zabudowanych w przodku szybowym, a szczególnie z ładowarką chwytakową. Proces drążenia wyrobiska polega na urabianiu dna szybu za pomocą frezującego organu ślimakowego i ładowaniu urobku ładowarką chwytakową. Własności urabianego górotworu oraz technologia pracy organu (pionowa oś jego obrotu - rys. 16) utrudniają urabianie dna szybu, na skutek jego obklejania. Dlatego w czasie pracy kombajnu wymagane są przerwy na czyszczenie organu urabiającego, a także ładowania urobku [9].

Mając powyższe na uwadze, w Katedrze MGPiT zaproponowano koncepcję nowej generacji kompleksu szybowego, który równolegle będzie realizował następujące procesy: urabianie wykonywane jako proces ciągły przez organ frezujący mocowany do platformy roboczej w sposób umożliwiający urabianie całego dna szybu, ładowanie i odstawa realizowane w sposób ciągły przez odkładnię (ładowarkę lemieszową) i zestaw przenośników taśmowych oraz kubełkowych i zabezpieczenie tymczasowe ociosów panelami stalowymi spełniającymi jednocześnie funkcję rozparcia za pomocą zintegrowanych siłowników hydraulicznych. Kompleks ten przeznaczony jest do drążenia szybów o średnicy 8,5-9,5 m. W omawianej koncepcji wykorzystano konstrukcje zaproponowane przez ITG KOMAG (układ rozpierania oraz ramię organu urabiającego). Opracowany na podstawie tej koncepcji model kompleksu szybowego przedstawiono na rysunku 17 [10]. 


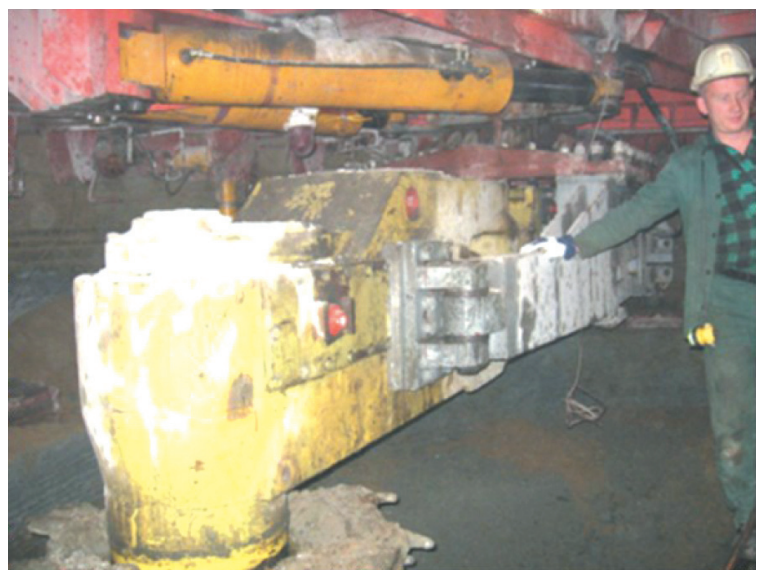

Rys. 16. Widok wysięgnika zawieszenia uktadu napędu organu urabiajacego wraz z głowica i organem urabiajacym w kombajnie szybowym KDS-2 [9]

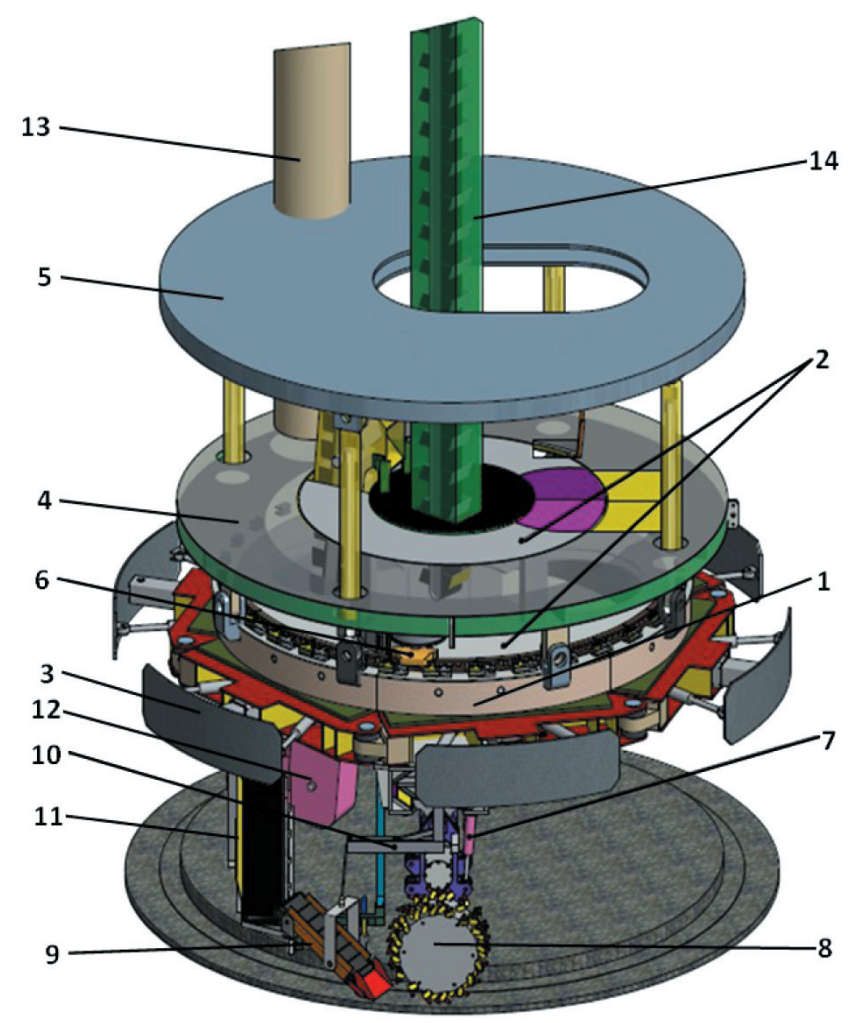

Rys. 17. Model opracowanego kompleksu szybowego [10]: 1 - platforma robocza, 2 - pierścień obrotowy, 3 - uktad rozpierający, 4 - nieruchomy podest roboczy, 5 - podest staty, 6 - napęd obrotu platformy roboczej, 7 - siłowniki podnoszenia ramienia, 8 - organ urabiający, 9 - przenośnik taśmowy krótki, 10 - układ podnoszenia przenośnika krótkiego, 11 - przenośnik taśmowy liniowy, 12 - przesyp i przenośnik kubetkowy krótki, 13 - lutniociag, 14 - przenośnik kubetkowy dhugi

Innowacyjnym rozwiązaniem kombajnu szybowego jest zespół urabiania i ładowania (rys. 18). W skład zespołu urabiania wchodzi ramię kombajnowe, dwa siłowniki podnoszenia ramienia, układ podnoszenia przenośnika krótkiego z ramieniem organu i organem urabiającym. Ramię kombajnowe jest adaptowanym ramieniem kombajnu ścianowego $\mathrm{z}$ organem frezującym napędzanym silnikiem o mocy $250 \mathrm{~kW}$.
Zawrębienie odbywa się za pomocą dwóch siłowników umieszczonych po jednej stronie ramienia. Podczas zawrębiania pierścień obrotowy platformy wykonuje obrót z prędkością roboczą.

Organ frezujący podczas ruchu pierścienia obrotowego platformy wykonuje skraw o przekroju prostokątnym i szerokości równej zabiorowi organu oraz wysokości równej głębokości urabiania. 


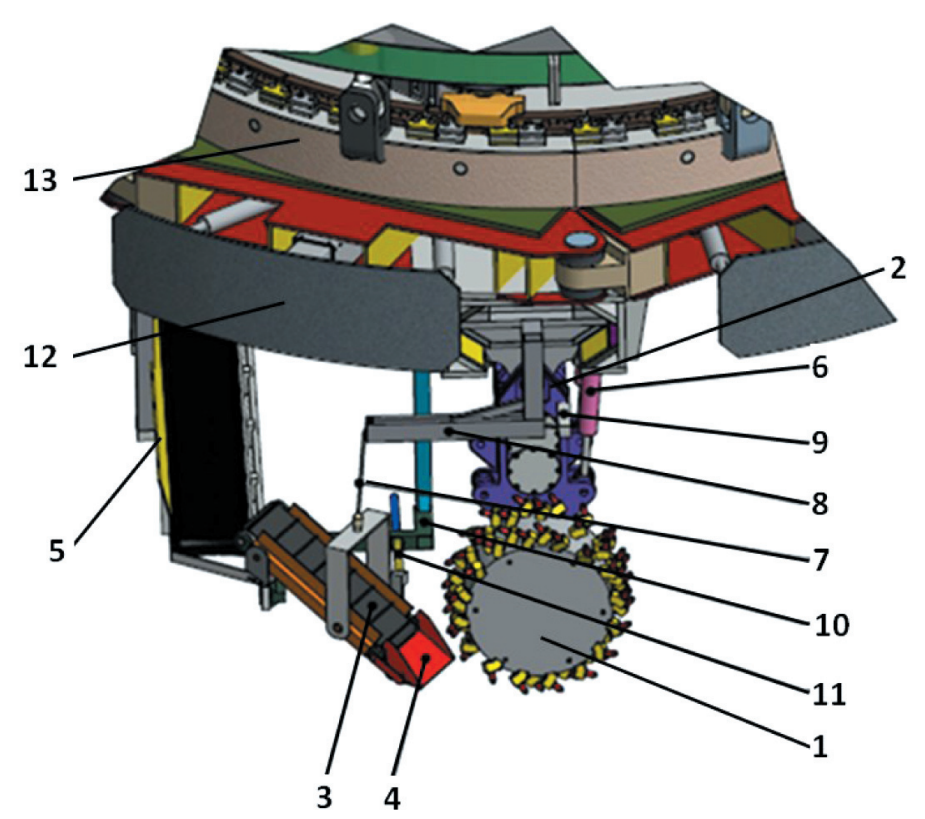

Rys. 18. Model opracowanego dla kompleksu szybowego innowacyjnego zespołu urabiania i tadowania [10]: 1 - organ urabiający, 2 - ramię, 3 - przenośnik taśmowy krótki, 4-zgarniak, 5 - przenośnik taśmowy liniowy, 6 - sitowniki podnoszenia ramienia, 7 - linka stalowa, 8 - uktad podnoszenia przenośnika krótkiego, 9 - mocowanie linki, 10 - uktad przesuwu przenośnika, 11 - siłownik obrotu przenośnika, 12 - układ rozpierajacy, 13 - pierścień obrotowy

Po wykonaniu jednego skrawu następuje uniesienie organu, a następnie ruch powrotny pierścienia obrotowego platformy do położenia wyjściowego. Konieczne jest zawrębienie organu $\mathrm{w}$ nowym skrawie, czyli w nowym położeniu, w kierunku do osi szybu o wartość zabioru organu. Podczas zawrębiania do kolejnych skrawów organ przemieszcza się po prowadnicy liniowej, w kierunku osi szybu równocześnie z obrotem pierścienia, co skutkuje spiralnym ruchem organu, aż do osiągnięcia położenia w nowym skrawie. Wykonanie kolejnych skrawów odbywa się analogicznie, aż do urobienia pełnej warstwy (rys. 19). W trakcie fazy zawrębiania oraz normalnego urabiania przenośnik taśmowy krótki przemieszcza się za organem i przekazuje urobek na przenośnik taśmowy poziomy (liniowy) [11].

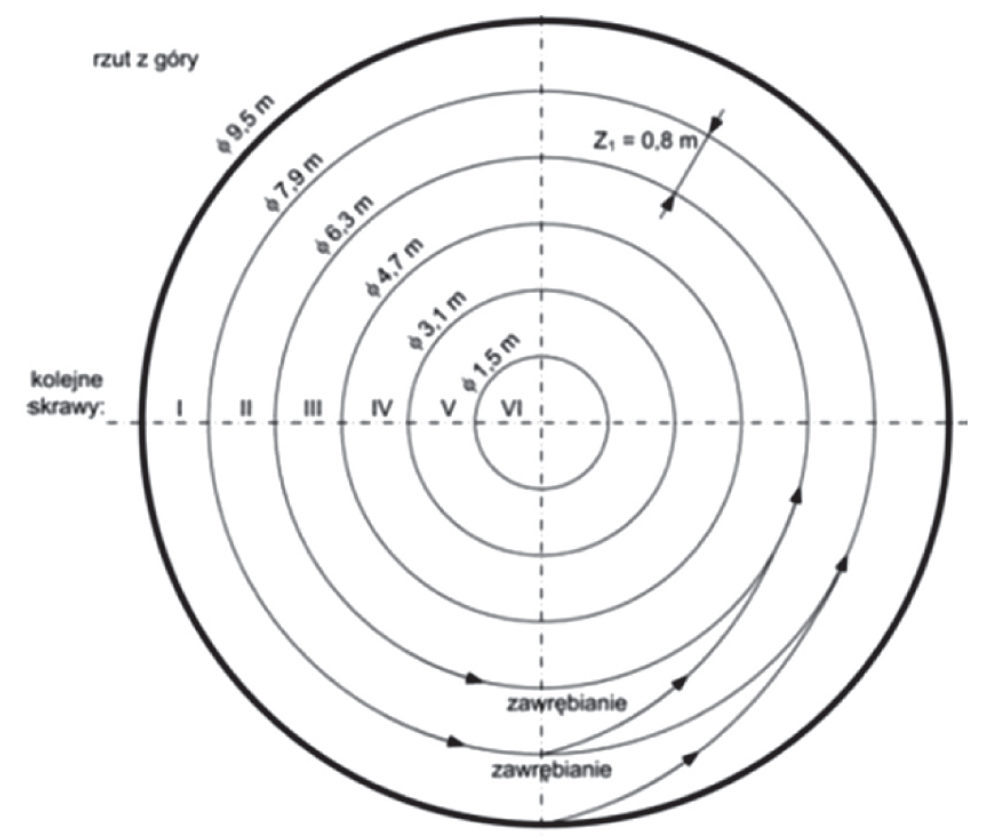

Rys. 19. Schemat technologii wykonania kolejnych skrawów dna szybu [11] 
Zespół przenośników jest ostatnim „ogniwem” zamkniętej pracy kombajnu szybowego. Urobek spod organu urabiającego, poprzez zgarniak i krótki przenośnik taśmowy ładowany jest na poziomy przenośnik taśmowy, a następnie przemieszczany do przesypu. Z przesypu urobek jest odbierany przez krótki przenośnik kubełkowy i transportowany do zasobnika. Z zasobnika przenośnik kubełkowy transportuje urobek poza platformę roboczą na zadaną przez użytkownika wysokość. Podniesienie krótkiego przenośnika realizowane jest za pomocą linki stalowej połączonej poprzez układ podnoszenia pomiędzy ramieniem kombajnu a krótkim przenośnikiem taśmowym. Wprowadzono również siłownik pozwalający na prostowanie się krótkiego przenośnika taśmowego względem przenośnika poziomego podczas przejazdu ramienia do środka szybu.

Przedmiotowy kompleks szybowy realizuje jednocześnie proces urabiania, ładowania i odstawy urobku z dna szybu. Szerokość skrawu organu została ustalona na $0,8 \mathrm{~m}$ przy dopuszczalnej wartości $1,0 \mathrm{~m}$. Zgodnie z przyjętymi założeniami urabianie odbywa się za pomocą organu frezującego o poziomej osi. Przed rozpoczęciem urabiania platforma robocza $\mathrm{z}$ kombajnem zostaje ustawiona $\mathrm{w}$ takiej odległości od dna szybu, aby możliwe było zawrębienie organu na głębokość do 0,3 m (maks. 0,35 m). Zawrębianie odbywa się za pomocą wychylnego ramienia organu. Podczas opuszczania platformy roboczej następuje również opuszczanie długiego przenośnika kubełkowego. Po ustaleniu i rozparciu platformy roboczej następuje faza zawrębiania. Podczas zawrębiania pierścień obrotowy platformy wykonuje ruch obrotowy z prędkością roboczą. Organ frezujący podczas ruchu pierścienia obrotowego platformy wykonuje skraw w kształcie toroidu o przekroju prostokątnym o szerokości równej szerokości organu. Po urobieniu jednego skrawu następuje uniesienie organu, a następnie ruch powrotny pierścienia obrotowego platformy do położenia wyjściowego. Następnie konieczne jest zawrębienie organu w nowym skrawie, czyli w nowym położeniu w kierunku do osi szybu o wartość zabioru organu, tak jak pokazano to na rysunku 19. W trakcie fazy zawrębiania oraz normalnego urabiania ładowarka lemieszowa przemieszcza się za organem i przekazuje urobek na zespół przenośników. Przenośnik kubełkowy długi transportuje urobek poza platformę roboczą na wymaganą wysokość wynikającą z zastosowanego wyposażenia kompleksu szybowego.
Po wykonaniu pełnej warstwy organ wraca do położenia wyjściowego i następuje wykonanie kolejnego skrawu z zabiorem $0,3 \mathrm{~m}$ poprzez opuszczenie platformy z kombajnem.

Przedstawiony kombajn szybowy różni się od dostępnych na rynku i znanych z literatury kompleksów. Charakteryzuje go budowa modułowa $\mathrm{z}$ szerokimi możliwościami modyfikacji, co przekłada się na wiele wariantów dostosowanych do różnych warunków pracy, potrzeb i wymagań użytkownika oraz wspótistniejących w wyrobisku maszyn i urządzeń.

\section{PODSUMOWANIE}

Przedstawione w artykule rozwiązania dotyczące maszyn i urządzeń są efektem prac badawczych prowadzonych w Katedrze MGPiT. Są to rozwiązania innowacyjne i niespotykane obecnie w górnictwie polskim. Część z nich została już poddana z powodzeniem próbom poligonowym, natomiast pozostałe rozwiązania na dzień dzisiejszy są w stadium przygotowania do opracowania projektów wstępnych i wykonania na ich podstawie egzemplarzy prototypowych. Można prognozować, że w niedalekiej przyszłości kilka z zaprezentowanych $\mathrm{w}$ artykule rozwiązań może zostać z sukcesem wykorzystanych w polskim górnictwie podziemnym.

\section{Literatura}

[1] Kotwica K., Gospodarczyk P., Stopka G., Kalukiewicz A.: The designing process and stand tests of a new solution of a mining head with disc tools of comple x motion trajectory for compact rocks mining, „Quarterly Mechanics and Control” 2010, 29, 3: 119-129.

[2] Kotwica K., Gospodarczyk P., Stopka G., Puchała B., Słowiński A.: Wyniki prób poligonowych głowicy urabiającej nowej generacji z narzędziami dyskowymi o ztożonej trajektorii ruchu, „Przegląd Górniczy” 2011, 11: 31-36.

[3] Kotwica K., Gospodarczyk P., Stopka G.: A new generation mining head with head with disc tool of complex trajectory, „Archives of Mining Sciences” 2013, 58, 4: 985-1006.

[4] Kotwica K., Krauze K., Wydro T.: Zastosowanie tymczasowej obudowy zmechanizowanej $w$ procesie drażenia wyrobisk korytarzowych, ,Zeszyty Naukowe Politechniki Śląskiej” 2007, 1765, 280: 311-325.

[5] Krauze K., Bołoz Ł., Wydro T.: Prototype of temporary mechanized mine roadway support of the dog headings. Theory and technique of coal mining and disaster prevention in deep mines, w: Proceedings of international mining conference, Anhui University of Science and Technology, China, 2014: 538-545.

[6] Krauze K., Bołoz Ł., Wydro T.: Urzadzenie do montażu łukowej obudowy podatnej w podziemnych wyrobiskach korytarzowych, Opis zgłoszeniowy wynalazku, PL 412667 A1, „Biuletyn Urzędu Patentowego", 2016: 33. 
[7] Bołoz Ł.: Unique project of single-cutting head longwall shearer used for thin coal seams exploitation, „Archives of Mining Sciences" 2013, 58, 4: 1057-1070.

[8] Krauze K., Bołoz Ł.: Model jednoorganowego frezującego kombajnu ścianowego, „Napędy i Sterownie” 2010, 12: 120-123.

[9] Kotwica K., Krauze K., Bołoz Ł., Twardak E.: Wpływ warunków górniczo-geologicznych $w$ drażonym szybie na prace organu urabiajacego kombajnu szybowego, in: Problemy bezpieczeństwa w budowie i eksploatacji maszyn i urządzeń górnictwa podziemnego, red. K. Krauze, Centrum Badań i Dozoru Górnictwa Podziemnego, Katowice-Lędziny 2010: 134-146.

[10] Krauze K., Bołoz Ł., Wydro T., Mucha K.: Kompleks szybowy nowej generacji, w: Mechanizacja, automatyzacja i roboty zacja w górnictwie. T. 2: Problemy eksploatacji i zarządzania $w$ górnictwie podziemnym $i$ odkrywkowym, red. K. Krauze CBiDGP Lędziny-Kraków 2017: 103-112.
[11] Krauze K., Bołoz Ł., Wydro T.: Zmechanizowany frezujacy kompleks szybowy, IV Polski Kongres Górniczy, Kraków 2017: 105-106.

prof. dr hab. inż. KRZYSZTOF KRAUZE

dr hab. inz. KRZYSZTOF KOTWICA, prof. AGH

Katedra Maszyn Górniczych, Przeróbczych

$i$ Transportowych

Wydziat Inżynierii Mechanicznej i Robotyki

AGH Akademia Górniczo-Hutnicza im. Stanistawa Staszica w Krakowie al. Mickiewicza 30, 30-059 Kraków \{krauze,kotwica\}@agh.edu.pl 